\title{
Article \\ Dual Inhibition of AKT and MEK Pathways Potentiates the Anti-Cancer Effect of Gefitinib in Triple-Negative Breast Cancer Cells
}

\author{
Kyu Sic You ${ }^{1,2,+} \mathbb{D}$, Yong Weon Yi ${ }^{3,+}+\underset{\mathbb{D}}{ }$, Jeonghee Cho ${ }^{3, *(\mathbb{D})}$ and Yeon-Sun Seong ${ }^{1,2,3, *}$ \\ 1 Graduate School of Convergence Medical Science, Dankook University, Cheonan 31116, Korea; \\ kisuhezu@gmail.com \\ 2 Department of Biochemistry, College of Medicine, Dankook University, Cheonan 31116, Korea \\ 3 Department of Nanobiomedical Science, Dankook University, Cheonan 31116, Korea; dragon101@gmail.com \\ * Correspondence: jeonghee.cho@dankook.ac.kr (J.C.); seongys@dankook.ac.kr (Y.-S.S.); \\ Tel.: +82-41-550-1172 (J.C.); +82-41-550-3875 (Y.-S.S.) \\ + These authors contributed equally to this work. \\ $\ddagger$ Current address: ExoCoBio Inc., Seoul 08594, Korea.
}

check for updates

Citation: You, K.S.; Yi, Y.W.; Cho, J.; Seong, Y.-S. Dual Inhibition of AKT and MEK Pathways Potentiates the Anti-Cancer Effect of Gefitinib in Triple-Negative Breast Cancer Cells. Cancers 2021, 13, 1205. https:// doi.org/10.3390/cancers13061205

Academic Editor: David Wong

Received: 23 January 2021

Accepted: 7 March 2021

Published: 10 March 2021

Publisher's Note: MDPI stays neutral with regard to jurisdictional claims in published maps and institutional affiliations.

Copyright: (c) 2021 by the authors. Licensee MDPI, Basel, Switzerland. This article is an open access article distributed under the terms and conditions of the Creative Commons Attribution (CC BY) license (https:// creativecommons.org/licenses/by/ $4.0 /)$.
Simple Summary: Triple-negative breast cancer (TNBC) is an intractable subset of breast cancer without an efficient therapeutic strategy due to the lack of tractable targets, such as the estrogen receptor, progesterone receptor, and human epidermal growth factor receptor 2 . Activation and/or amplification of epidermal growth factor receptor (EGFR), phosphoinositide 3-kinase (PI3K)/v-akt murine thymoma viral oncogene homolog (AKT), and MAPK/ERK kinase (MEK)/ extracellular signal-regulated kinase (ERK) pathways is known in TNBC; however, interventions for these targets have not been successful to date. To explore a combinatorial strategy with existing clinical/preclinical protein kinase inhibitors (PKIs) in TNBC cells, we performed a series of cytotoxicity (cell viability) screenings with various PKIs in the presence figure of an EGFR inhibitor, gefitinib. The dual inhibition of AKT and MEK with gefitinib reduced the proliferation and colony formation of TNBC cells by inducing apoptosis. Our finding suggests a new approach for treating TNBC with a multiplex combination of PKIs.

Abstract: There is an unmet medical need for the development of new targeted therapeutic strategies for triple-negative breast cancer (TNBC). With drug combination screenings, we found that the triple combination of the protein kinase inhibitors (PKIs) of the epidermal growth factor receptor (EGFR), $\mathrm{v}$-akt murine thymoma viral oncogene homolog (AKT), and MAPK/ERK kinase (MEK) is effective in inducing apoptosis in TNBC cells. A set of PKIs were first screened in combination with gefitinib in the TNBC cell line, MDA-MB-231. The AKT inhibitor, AT7867, was identified and further analyzed in two mesenchymal stem-like (MSL) subtype TNBC cells, MDA-MB-231 and HS578T. A combination of gefitinib and AT7867 reduced the proliferation and long-term survival of MSL TNBC cells. However, gefitinib and AT7867 induced the activation of the rat sarcoma (RAS) / v-raf-1 murine leukemia viral oncogene homolog (RAF)/MEK/ extracellular signal-regulated kinase (ERK) pathway. To inhibit this pathway, MEK/ERK inhibitors were further screened in MDA-MB-231 cells in the presence of gefitinib and AT7867. As a result, we identified that the MEK inhibitor, PD-0325901, further enhanced the anti-proliferative and anti-clonogenic effects of gefitinib and AT7867 by inducing apoptosis. Our results suggest that the dual inhibition of the AKT and MEK pathways is a novel potential therapeutic strategy for targeting EGFR in TNBC cells.

Keywords: AKT; anti-cancer; combination; EGFR resistance; MEK; protein kinase inhibitor (PKI); synergism; triple-negative breast cancer (TNBC) 


\section{Introduction}

Triple-negative breast cancer (TNBC) is defined clinically as being negative for both the estrogen receptor (ER) and progesterone receptor (PR) and having no amplification of human epidermal growth factor receptor 2 (HER2) [1,2]. Therefore, the therapeutic options that feature drugs targeting these proteins are not available for TNBC patients. TNBC accounts for approximately $15-20 \%$ of breast cancers and is known as the most aggressive breast cancer [1-6]. Although TNBCs respond well to conventional adjuvant chemotherapies, including taxanes, anthracyclines, capecitabines, and/or platins, resistance to these agents and distant metastasis diminish overall prognosis [7-10]. Experimental therapeutics against specific targets, such as acetylated signal transducer and activator of transcription 3 (STAT3) and mutant p53 in TNBC cells, have been developed [11-13]. Up to date, four targeted therapies have been approved by the US Food and Drug Administration (FDA). These therapies include the poly [adenosine diphosphate (ADP)-ribose] polymerase 1 (PARP1) inhibitors, olaparib and talazoparib; the programmed cell death ligand 1 (PD-L) inhibitor, atezolizumab; and antibody drug conjugates (ADCs), sacituzumab govitecan [2]. However, most treatments exhibit limited durable clinical responses [2].

The epidermal growth factor receptor (EGFR) is a member of the human epidermal growth factor receptor (HER) family, which consists of four receptor tyrosine kinases that are important for the proliferation and survival of normal cells [14-16]. EGFR is activated via epidermal growth factor (EGF) binding, which then promotes intracellular signaling pathways, such as rat sarcoma (RAS)/v-raf-1 murine leukemia viral oncogene homolog (RAF)/MAPK/ERK kinase (MEK)/extracellular signal-regulated kinase (ERK), phosphoinositide 3-kinase (PI3K)/v-akt murine thymoma viral oncogene homolog (AKT)/mammalian target of rapamycin (mTOR), and v-src avian sarcoma (Schmidt-Ruppin A-2) viral oncogene homolog (SRC)/signal transducer and activator of transcription (STAT) [17-19]. Activation of EGFR, that caused by EGFR gene amplification or mutations, or protein overexpression, or point mutations has been reported in many cancer types. EGFR is a well-established therapeutic target; many small-molecule kinase inhibitors and monoclonal antibodies have been approved for treating several human cancers by the US FDA $[15,16]$. High EGFR expression has been reported in $>50 \%$ of TNBC, which is associated with a poor prognosis $[1,3,14,15,20]$. Lehmann et al. have classified TNBC into six subtypes and shown that two of them have the active EGFR pathway: basal-like 2 (BL2) and mesenchymal stem-like (MSL) subtypes [5]. However, TNBC has displayed intrinsic resistance to anti-EGFR therapeutics $[3,20]$. One possible explanation is that most TNBCs are not solely dependent on the EGFR pathway for their survival because of rare EGFR-activating mutations [3]. Most anti-EGFR therapeutics are effective in cancers that have activated mutations in EGFR.

Combining existing therapeutics is a promising way to treat intractable cancers, such as pancreatic cancer or TNBC [2,21-34]. For example, blocking the PI3K/AKT pathway [25], MET [30], or mammalian target of rapamycin complex 1 (mTORC1) [33] sensitized TNBC cells to EGFR inhibitors (EGFRis). A combination of EGFRi, gefitinib, or erlotinib with $\mathrm{PI} 3 \mathrm{~K} / \mathrm{AKT}$ inhibitors resulted in the synergism of an anti-proliferative effect in the cell lines of the BL subtype [25]. However, these combinations have no synergism in the MSL subtype cell lines. Additionally, we determined that co-treatment with the MET inhibitor (METi), SU11274, and EGFRis has a synthetic lethality in MSL TNBC cells though the downregulation of ribosomal protein S6 (RPS6) [30]. Additionally, inhibiting the mTORC1 pathway via the AKT inhibitor, MK2206, or blocking the regulatory-associated protein of mTOR (RPTOR) with small interfering RNA (siRNA) potentiated gefitinib toxicity in TNBC cells [33]. Recently, more efficacious treatments for TNBC have been suggested that use a triple combination of drugs targeting multiple pathways simultaneously, such as redox homeostasis, DNA synthesis, DNA damage, histone deacetylase, and multiple protein kinases [35-37]. A drug combination discovery involving 33 FDA-approved PKIs revealed that the triple combination of dasatinib, afatinib (BIBW-2992), and trametinib (GSK1120212) was anti-proliferative in TNBC cells by inhibiting SRC, HER2/EGFR, and MEK [37-40]. 
In this paper, we showed that the dual blocking of the AKT and MEK pathways sensitized TNBC cells to the EGFRi, gefitinib. A set of small-molecule PKIs were screened in combination with gefitinib for the MSL subtype cell, MDA-MB-231. An AKT inhibitor (AKTi), AT7867, was identified as the most potent inhibitor, which we further analyzed using two MSL subtype TNBC cells, MDA-MB-231 and HS578T. A combination of gefitinib and AT7867 reduced the proliferation and long-term survival of MSL TNBC cells. However, gefitinib and AT7867 (hereafter referred to as Gefi+AT7867) induced the activation of the MEK/ERK pathway. Blocking this pathway with the MEK inhibitor (MEKi), PD-0325901, further enhanced the anti-cancer effect of Gefi+AT7867. Our results suggest that the dual inhibition of the AKT and MEK pathways is a potential therapeutic strategy for targeting EGFR in TNBC cells.

\section{Materials and Methods}

\subsection{Cell Culture and Reagents}

The MDA-MB-231 and HS578T cell lines were obtained from the American Type Culture Collection (ATCC; Manassas, VA, USA). Cells were cultured in Dulbecco's modified Eagle's medium (DMEM; HyClone, Logan, UT, USA) supplemented with 10\% fetal bovine serum (FBS; Corning, Manassas, VA, USA) and 100 units/mL penicillin/streptomycin (Thermo Fisher Scientific, Waltham, MA, USA). The viability of cultured cells were monitored by the Trypan Blue dye exclusion method using an automated cell counter, as described previously [41]. The PKIs used in this study were reported in Table 1.

Table 1. Protein kinase inhibitors (PKIs) used in 3-(4,5-dimethylthiazol-2-yl)-2,5-diphenyltetrazolium bromide (MTT) screening.

\begin{tabular}{|c|c|c|c|c|}
\hline PKI & Other Name & Known Targets $\left(\mathrm{IC}_{50}\right.$ Value in $\left.\mathrm{nM}\right)$ & Source & Ref \\
\hline A-769662 & & $\operatorname{AMPK}\left(800 ; \mathrm{EC}_{50}\right)$ & $\begin{array}{c}\text { LC Laboratories } \\
\text { (Woburn, MA, USA) }\end{array}$ & {$[42]$} \\
\hline AT7867 & & $\begin{array}{l}\text { AKT2 (17), PKA (20), AKT1 (32), } \\
\text { AKT3 (47), p70S6K (85) }\end{array}$ & \multirow{6}{*}{$\begin{array}{l}\text { Selleck Chemicals } \\
\text { (Houston, TX, USA) }\end{array}$} & [43] \\
\hline AT9283 & & $\begin{array}{c}\text { JAK3 (1.1), JAK2 (1.2), AURKA ( 3.0), } \\
\text { AURKB ( 3.0), ABL1 }{ }^{\text {T315I }}(4)\end{array}$ & & {$[44]$} \\
\hline AZD1152-HQPA & Barasertib, AZD2811 & AURKB (0.37) & & [45] \\
\hline AZD1480 & & JAK2 (0.26) & & [46] \\
\hline BI 2536 & & PLK1 (0.83), PLK2 (3.5) & & {$[47,48]$} \\
\hline BIX 02189 & & MEK5 (1.5) & & [49] \\
\hline BML-275 & $\begin{array}{l}\text { Dorsomorphin, } \\
\text { Compound C }\end{array}$ & AMPK (109; Ki) & $\begin{array}{l}\text { Tocris Bioscience } \\
\text { (Bristol, UK) }\end{array}$ & [50] \\
\hline Bosutinib & SKI-606 & ABL (1), SRC (1.2) & \multirow{2}{*}{ LC Laboratories } & {$[51,52]$} \\
\hline Chelerythrine & & PKC (660) & & [53] \\
\hline CHIR-99021 & СТ99021 & GSK3 $\beta$ (6.7), GSK3 $\alpha(10)$ & \multirow{2}{*}{ Selleck Chemicals } & [54] \\
\hline CI-1040 & PD184352 & MEK1 (17), MEK2 (17) & & [55] \\
\hline CP690550 & Tofacitinib & JAK3 (1), JAK2 (20) & LC Laboratories & [56] \\
\hline CYC116 & & $\begin{array}{l}\text { AURKA }(8 ; \mathrm{Ki}), \operatorname{AURKB}(9 ; \mathrm{Ki}), \\
\text { VEGFR2 }(44 ; \mathrm{Ki}), \text { FLT3 }(44 ; \mathrm{Ki})\end{array}$ & \multirow{3}{*}{ Selleck Chemicals } & [57] \\
\hline Danusertib & PHA-739358 & $\begin{array}{l}\text { AURKA (13), ABL (25), RET (31), } \\
\text { TRKA (31), FGFR1 (47), AURKC (61), } \\
\text { AURKB (79) }\end{array}$ & & {$[58]$} \\
\hline Enzastaurin & LY317615 & $\begin{array}{c}\mathrm{PKC} \beta \text { (6), } \mathrm{PKC} \alpha(39), \mathrm{PKC} \gamma(83), \\
\mathrm{PKC} \varepsilon(110)\end{array}$ & & [59] \\
\hline
\end{tabular}


Table 1. Cont.

\begin{tabular}{|c|c|c|c|c|}
\hline PKI & Other Name & Known Targets $\left(\mathrm{IC}_{50}\right.$ Value in $\left.\mathrm{nM}\right)$ & Source & Ref \\
\hline Fasudil & HA-1077 & ROCK2 (330) & LC Laboratories & [60] \\
\hline FR 180204 & & ERK2 (140), ERK1 (310) & Tocris Bioscience & [61] \\
\hline GDC-0879 & AR-00341677 & BRAF (0.13) & Selleck Chemicals & [62] \\
\hline GW 843682X & & PLK1 (2.2), PLK3 (9.1) & Tocris Bioscience & [63] \\
\hline $\mathrm{I} 3 \mathrm{M}$ & & GSK3 $\beta(190)$ & $\begin{array}{l}\text { Calbiochem (San Diego, } \\
\text { CA, USA) }\end{array}$ & [64] \\
\hline IKK 16 & IKK Inhibitor VII & $\begin{array}{c}\text { IKK2 (40), IKK complex (70), } \\
\text { IKK1 (200) }\end{array}$ & Tocris Bioscience & [65] \\
\hline Imatinib & $\begin{array}{l}\text { STI571, CGP057148B, } \\
\text { Gleevec }\end{array}$ & PDGFR (100), c-KIT (100), v-ABL (600) & LC Laboratories & [66] \\
\hline INCB018424 & Ruxolitinib & JAK2 (2.8), JAK1 (3.3) & \multirow{5}{*}{ Selleck Chemicals } & [67] \\
\hline JNJ-7706621 & & $\begin{array}{c}\text { CDK2/Cyclin E (3), CDK2/Cyclin A } \\
\text { (4), CDK1/Cyclin B (9), AURKA (11), } \\
\text { AURKB (15) }\end{array}$ & & [68] \\
\hline KU-55933 & & ATM (12.9) & & [69] \\
\hline LY2228820 & Ralimetinib & $\mathrm{P} 38 \alpha(7)$ & & [70] \\
\hline MLN8237 & Alisertib & AURKA (1.2) & & [71] \\
\hline Nilotinib & AMN-107 & Bcr-Abl $(<30)$ & LC Laboratories & [72] \\
\hline NSC 109555 & & CHK2 (200) & \multirow{2}{*}{ Tocris Bioscience } & [73] \\
\hline NU 7441 & KU-57788 & DNA-PK (14) & & [74] \\
\hline PD-0325901 & Mirdametinib & MEK (0.33) & Selleck Chemicals & [75] \\
\hline PD407824 & & CHK1 (47), WEE1 (97) & Tocris Bioscience & [76] \\
\hline PF-4708671 & & p70S6K1 (160) & Selleck Chemicals & [77] \\
\hline PF 573228 & & FAK (4) & Tocris Bioscience & [78] \\
\hline PKC412 & $\begin{array}{l}\text { Midostaurin, CGP } \\
41251\end{array}$ & $\begin{array}{c}\mathrm{PKC} \alpha(22), \mathrm{PKC} \gamma(24), \mathrm{PKC} \beta 1(30) \\
\mathrm{PKC} \beta 2(31), \mathrm{PPK}(38)\end{array}$ & LC Laboratories & [79] \\
\hline PLX-4032 & Vemurafenib & $\begin{array}{l}\text { SRMS (18), ACK (19), BRAF (31), } \\
\text { C-RAF (48), MAP4K5 (51) }\end{array}$ & \multirow{2}{*}{ Selleck Chemicals } & [80] \\
\hline PLX-4720 & & $\begin{array}{c}\text { BRAFV600E }(13) \\
\text { C-RAF1 }^{\text {Y340D/Y341D }}(6.7)\end{array}$ & & [81] \\
\hline Ro-31-8220 & Bisindolylmaleimide IX & $\begin{array}{c}\mathrm{PKC} \alpha(5), \mathrm{PKC} \beta 2(14), \mathrm{PKC} \beta 1(24) \\
\mathrm{PKC} \varepsilon(24), \mathrm{PKC} \gamma(27)\end{array}$ & Calbiochem & [82] \\
\hline Roscovitine & Seliciclib, CYC202 & CDK5/P35 (160) & LC Laboratories & [83] \\
\hline SB216763 & & GSK3 $\alpha(34.3)$, GSK3 $\beta(\sim 34.3)$ & Selleck Chemicals & [84] \\
\hline SB 218078 & & CHK1 (15) & Tocris Bioscience & [85] \\
\hline SNS-032 & BMS-387032 & CDK9/Cyclin T (4) & \multirow{3}{*}{ Selleck Chemicals } & [86] \\
\hline SNS-314 & & AURKC (3), AURKA (9), AURKB (31) & & [87] \\
\hline SP600125 & NSC75890 & $\begin{array}{c}\text { JNK1 (40), JNK2 (40), AURKA (60), } \\
\text { TRKA (70) }\end{array}$ & & [88] \\
\hline TBCA & & CK2 (110) & $\begin{array}{l}\text { Millipore (Burlington, } \\
\text { MA, USA) }\end{array}$ & [89] \\
\hline TCS 2312 & & CHK1 $\left(60 ; \mathrm{EC}_{50}\right)$ & \multirow{3}{*}{ Tocris Bioscience } & [90] \\
\hline TC PIM-1-1 & SC 204330 & PIM (50) & & [91] \\
\hline TCS PIM-1-4a & SMI-4a & PIM1 (17) & & [92] \\
\hline
\end{tabular}


Table 1. Cont.

\begin{tabular}{|c|c|c|c|c|}
\hline PKI & Other Name & Known Targets $\left(\mathrm{IC}_{50}\right.$ Value in $\left.\mathrm{nM}\right)$ & Source & Ref \\
\hline Tozasertib & VX-680, MK-0457 & $\begin{array}{c}\text { AURKA }(0.6 ; \mathrm{Ki}), \operatorname{AURKC}(4.6 ; \mathrm{Ki}), \\
\text { AURKB }(18 ; \mathrm{Ki}), \mathrm{FLT3}(30 ; \mathrm{Ki}) \\
\text { BCL-ABL }(30 ; \mathrm{Ki})\end{array}$ & LC Laboratories & {$[93,94]$} \\
\hline TPCA-1 & GW683965 & IKK2 (17.9) & Tocris Bioscience & [95] \\
\hline U0126 & & MEK2 (60), MEK1 (70) & $\begin{array}{c}\text { Promega (Madison, WI, } \\
\text { USA) }\end{array}$ & [96] \\
\hline VX-702 & & $\mathrm{P} 38 \alpha(4-20)$ & \multirow{3}{*}{ Selleck Chemicals } & [97] \\
\hline Y-27632 & & ROCK1 (140; Ki); ROCK2 (300; Ki) & & {$[98,99]$} \\
\hline ZM-447439 & & AURKA (110), AURKB (130) & & [100] \\
\hline
\end{tabular}

\subsection{PKI Screening}

A synthetic lethality screening of PKIs was performed, as described previously $[30,33]$. Briefly, MDA-MB-231 cells were plated at 1000 cells/well in 96-well plates and incubated for $24 \mathrm{~h}$. The cells were treated with increasing concentrations of gefitinib and PKIs in duplicate in a $6 \times 5$ matrix that included a dimethyl sulfoxide (DMSO) vehicle control. The viability of cells was determined at $72 \mathrm{~h}$ after treatment with $4 \mathrm{mg} / \mathrm{mL}$ of 3-(4,5-dimethylthiazol2-yl)-2,5-diphenyltetrazolium bromide (MTT), as described previously $[11,25,101]$. The classification index $(\mathrm{CI})$ was calculated to determine synergism of the combination, as described previously [30,33]: $\mathrm{CI}=$ (viability with gefitinib) $\times$ (viability with PKI) / (viability with the gefitinib and PKI combo). CI $>1$, supra-additivity; $C I=1$, additivity; and $\mathrm{CI}<1$, sub-additivity. The numbers of combination points with $\mathrm{CI}>1.3$ were assigned as quantitative indices of synergism.

\subsection{Clonogenic Survival Assay}

Cells were seeded and cultured in 6-well plates, as described previously [33]. Cells in each well were treated with indicated drugs, and the colonies were stained with crystal violet solution as previously described [30]. After washing the colonies with distilled water, they were imaged with an image scanner.

\subsection{Western Blot Analysis}

For the treatment of PKI, the cells were plated at $2 \times 10^{5}$ cells $/ 60-\mathrm{mm}$ dish and incubated for approximately $24 \mathrm{~h}$. Next, cells were treated with PKIs for $2 \mathrm{~h}$ or $24 \mathrm{~h}$ in normal growth media supplemented with FBS. Following treatment, the cells were lysed with a radioimmunoprecipitation assay (RIPA) buffer containing a protease and phosphatase inhibitor cocktail (ThermoFisher Scientific, Waltham, MA, USA). The protein concentration was measured via bicinchoninic acid (BCA) assay (Thermo Fisher Scientific, Waltham, MA, USA). The antibodies used in this study as follows: mTOR, p-mTOR (S2448), ERK1/2, p-ERK1/2 (T202/Y204), RPS6, p-RPS6 (S235/236), AKT, p-AKT (S473), glycogen synthase kinase-3 beta (GSK3 $\beta$ ), p-GSK3 $\beta$ (S9), p-p90 ribosomal S6 kinase (RSK) (S380), p90RSK, p-STAT3 (T705), STAT3, cleaved caspase-3, and peroxidase-conjugated secondary antibodies (anti-rabbit IgG and anti-mouse IgG) from Cell Signaling Technology (Denver, MA, USA); XIAP from BD Sciences (San Jose, CA, USA); $\beta$-actin from Bethyl Laboratories (Montgomery, TX, USA); and $\beta$-tubulin from Sigma-Aldrich (St. Louis, MI, USA).

\subsection{Cell Cycle Analysis}

Cells were plated at $1 \times 10^{5}$ cells in 60 -mm dishes one day before treatment. Following the drug treatment, both adherent and floating cells were collected and fixed using $70 \%$ ethanol, as described previously [33]. The nuclei were stained with propidium iodide (PI) (Sigma-Aldrich; St. Louis, MI, USA), and the DNA contents were determined using a FACSCalibur Flow Cytometer (BD Sciences; Franklin Lakes, NJ, USA). The data were 
analyzed using CellQuest Pro (BD Sciences; Franklin Lakes, NJ, USA) and the ModFit LT $^{\mathrm{TM}}$ program (Verity Software House; Topsham, ME, USA).

\subsection{Antibody Array}

An antibody array analysis was performed by Fullmoon Biosystems (Sunnyvale, CA, USA) through ebiogen (Seoul, Korea). In brief, the protein extracts were purified by a gel matrix column. The protein extract quality was accessed via BCA protein assay with wavelength scanning using a spectrophotometer Model 680 (Bio-Rad Laboratories, Hercules, CA, USA). Fifty micrograms of each protein extract were used to label and probe the antibody array. Fluorescence signals were captured using the GenePix 4000B Microarray Scanner (Molecular Devices; San Jose, CA, USA). The signal intensity of each spot was normalized using global normalization.

\subsection{Statistical Analysis}

All experiments were performed at least three times in triplicate. Representative data are presented as means \pm standard deviation (SD). The differences between groups were determined by the One-way analysis of variance (ANOVA) with a post-hoc Tukey's honest significance difference (HSD) test. Data were considered statistically significant when $p<0.05$.

\section{Results}

3.1. Identification of AT7867 as a Potentiator of Gefitinib in MDA-MB-231 Cells

Previously, we identified a series of PKIs that potentiate TNBC cells' sensitivity to EGFRis $[25,30,33]$. Our studies also revealed the differential susceptibility of EGFRis and PKI combinations in subtypes of TNBC cells in vitro; MSL subtype cells are more resistant to PI3K/AKTi and EGFRi combinations than BL subtype cells [25]. This may be due to alternative survival pathways [102-107]. To further identify synergistic anti-cancer effects in MSL TNBC cells that overcome EGFRi resistance, we performed a synthetic lethality MTT screening with a new set of PKIs in combination with the EGFRi, gefitinib, in MDA-MB-231 cells. Among 55 PKIs tested, AT7867 was identified as the most promising PKI with a CI larger than 1.3, in 8 combination points from the $6 \times 5$ combination matrix (Figure 1A,B). In addition, its mean CI was relatively high (1.95; Figure 1A). AT7867 is an adenosine triphosphate (ATP)-competitive small-molecule PKI of AKT and its downstream kinase, p70 S6 kinase (p70S6K), as well as of protein kinase A (PKA) [43]. The synergistic effect of AT7867 and gefitinib was observed in a series of concentrations at different combination ratios in MDA-MB-231 cells (Figure 1C). The synthetic lethal effect of AT7867 with gefitinib was also confirmed in an additional MSL cell, HS578T (Figure 1C).

\subsection{Induction of Tetraploid Cells by AT7867}

The effect of the Gefi+AT7867 treatment for $72 \mathrm{~h}$ on cell cycle distribution was determined in MDA-MB-231 cells. The cell cycle distribution was determined by flow cytometric analysis (Figure 2). Gefitinib treatment alone did not alter cell cycle progression in MDAMD-231 cells; however, AT7867 induced an increase in the population of tetraploid cells (Figure 2A). Gefi+AT7867 further induced an increase of the gap 1 (G1) population with a concomitant reduction of the synthesis (S) and gap 2 (G2) populations in tetraploid cells (Figure 2B). Failures in spindle assembly, chromosome segregation, or cytokinesis followed by mitosis cause tetraploidy [108]. 

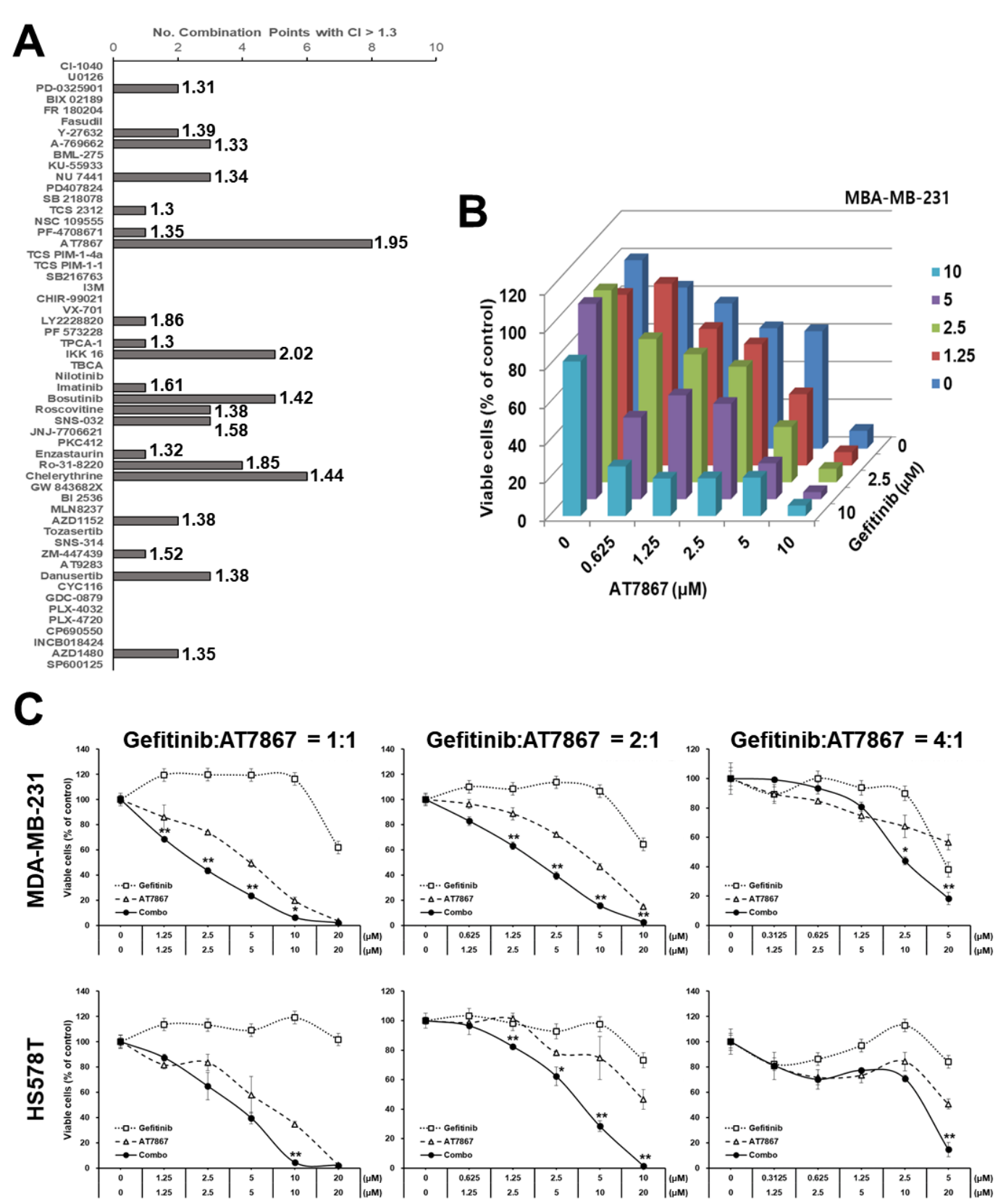

Figure 1. Treatment with AT7867 induced triple-negative breast cancer (TNBC) cells' sensitivity to gefitinib. (A) PKI + gefitinib screening results in MDA-MB-231 cells. The numbers of combination points with $\mathrm{CI}>1.3$ was indexed (see the Materials and Methods). The numbers on the right of each bar are the mean CI values of indicated drugs. (B) MTT screening results for AT7867 with gefitinib. MDA-MB-231 cells were treated with an increasing concentrations of AT7867 and gefitinib for $72 \mathrm{hr}$. The viable cells was measured by MTT assay. (C) The combination effect of gefitinib with AT7867 in two MSL TNBC cells. Data represent mean $\pm \mathrm{SD}$ from at least three independent experiments performed in triplicate. ${ }^{*} p<0.05$ and ${ }^{* *} p<0.01$. 
A
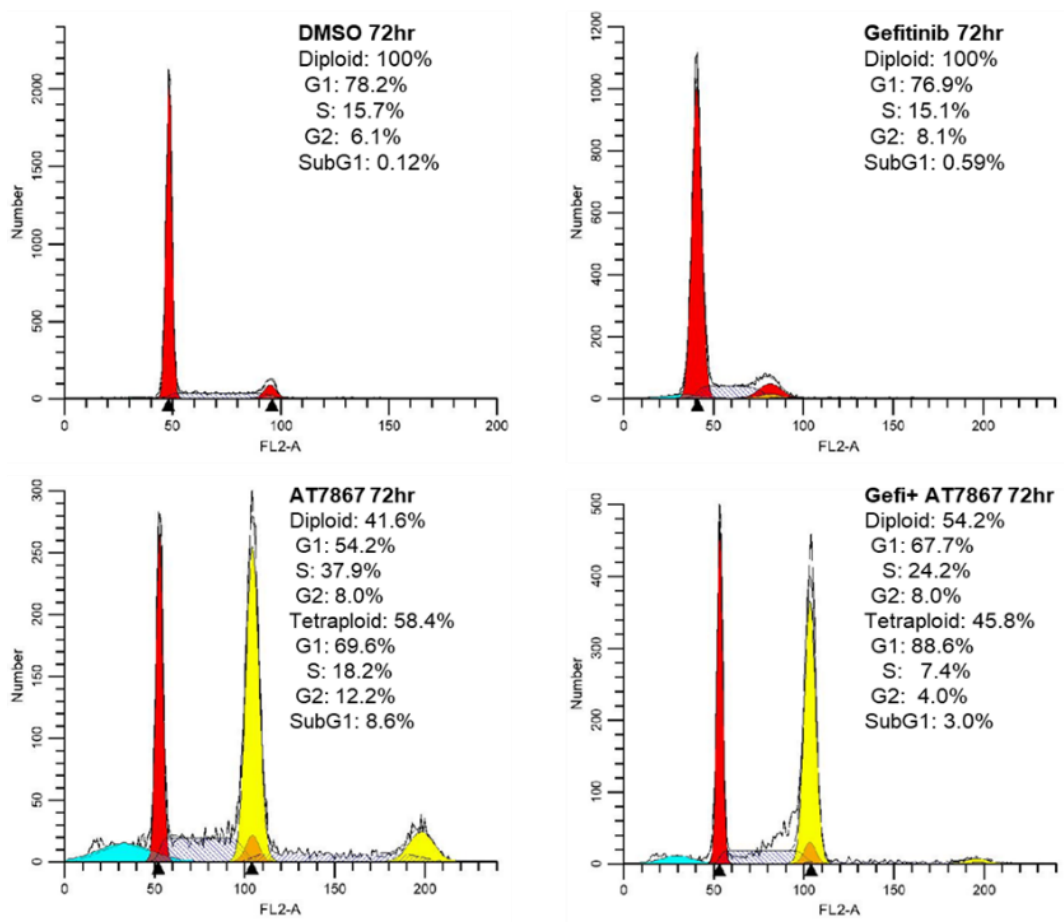

B

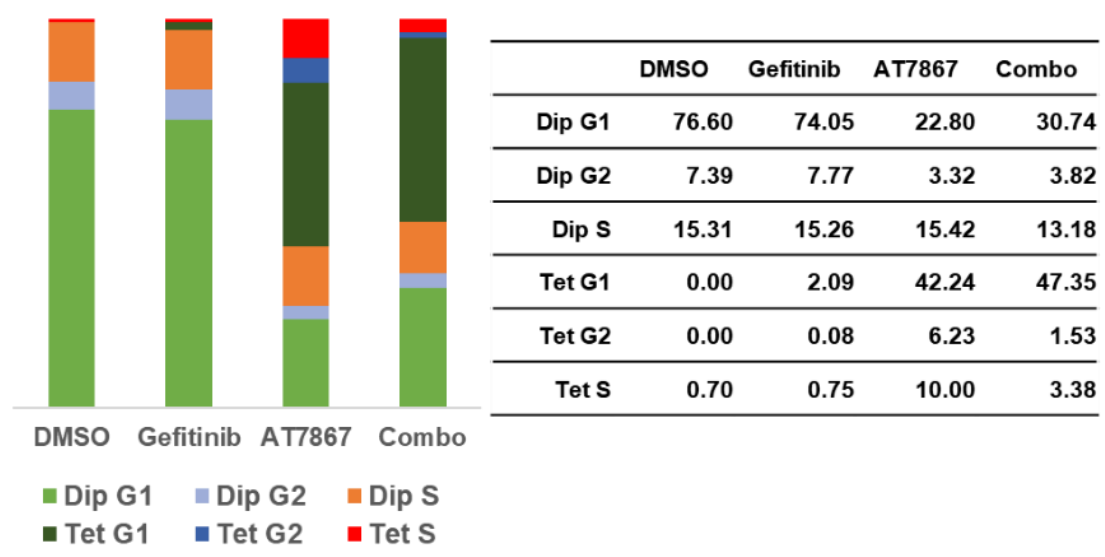

Figure 2. A combination of AT7867 and gefitinib-induced tetraploid gap 1 (G1) arrest in MDA-MB231 cells. (A) Representative histograms of cell cycle analysis in MDA-MB-231 cells in the presence of each drug or gefitinib and AT7867 (Gefi+AT7867). (B) Relative distribution of cell cycle phases.

\subsection{Gefitinib and AT7867 Reduced TNBC Cell Survival}

The clonogenic long-term survival of cancer cells was determined to analyze the effect of Gefi+AT7867 treatment. MDA-MB-231 and HS578T cells were subcultured in 6-well plates and treated with drug combinations for $24 \mathrm{~h}$. After washing, the cells were cultivated in normal growth media to form surviving colonies. As expected, gefitinib alone did not suppress the formation of colonies of MDA-MB-231 and HS578T cells (Figure 3A). In contrast to the MTT assay results, AT7867 alone markedly reduced the formation of colonies in both cell types, leading to $<40 \%$ colony formation when compared with vehicle-treated control cells (Figure 3B). Gefi+AT7867 treatment further reduced the number of colonies in both cells, reaching a statistically significant difference compared with AT7867 alone in MDA-MB-231 cells, but not in HS578T cells. Unfortunately, the complete abolition of colony formation was not achieved by Gefi+AT7867 in either cell type under this condition. 

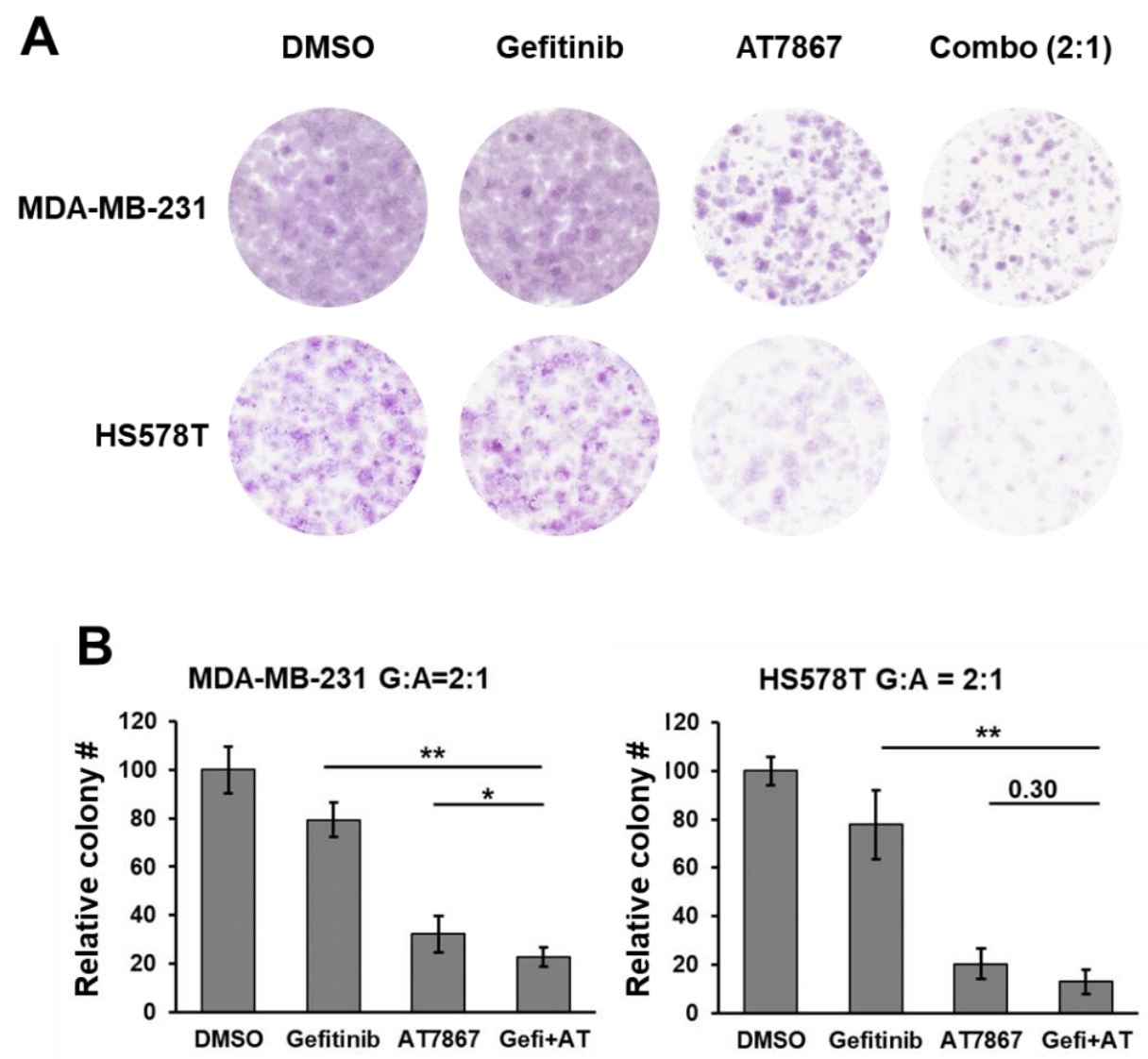

Figure 3. Gefitinib and AT7867 reduced the survival of MSL subtype TNBC cells. (A) MDA-MB-231 and HS578T cells were treated with $10 \mu \mathrm{M}$ Gefitinib, $5 \mu \mathrm{M}$ AT7867, or $10 \mu \mathrm{M}$ Gefitinib $+5 \mu \mathrm{M}$ AT7867 (Gefi+AT) for $24 \mathrm{~h}$ in normal growth media. Then, cells were washed and cultivated for additional 10-14 days in normal growth media. The colonies were stained as described in the Materials and Methods. Representative images are shown from three independent experiments performed in triplicate (B) The relative colony number was determined and presented as mean \pm SEM from three independent experiments performed in triplicate. ${ }^{*} p<0.05$ and ${ }^{* *} p<0.01$.

\subsection{Regulation of Signaling Pathways in TNBC Cells by Gefitinib and AT7867 Treatment}

Next, we analyzed the signaling pathways modulated by the Gefi+AT7867 treatment in TNBC cells. As expected, a $2 \mathrm{~h}$ treatment of gefitinib was not sufficient to downregulate the AKT pathway, as evident by no significant reduction in the levels of phospho (p)-AKT [25], p-mTOR, and p-GSK3 $\beta$ in MDA-MB-231 and HS578T cells (Figure 4, left). However, the levels of p-RPS6 were reduced by gefitinib alone. Serine 235/236 residues of RPS6 are phosphorylated by multiple protein kinases, including S6 kinase (S6K), ribosomal S6 kinase (RSK), casein kinase 1 (CK1), and protein kinase A (PKA) [109]. The key signaling pathways of p-RPS6 (S235/236) are PI3K/AKT/mTORC1/S6K and RAS/RAF/MEK/ERK/RSK [109]; therefore, gefitinib-induced downregulation of p-RPS6 might be mediated by the RAS/RAF/MEK/ERK/RSK pathway. However, the levels of p-ERK1/2 were increased by gefitinib treatment in MDA-MD-231 and HS578T cells. Additionally, gefitinib did not suppress the levels of p-STAT3 and p-p90RSK in these cells after a $2 \mathrm{~h}$ treatment. 


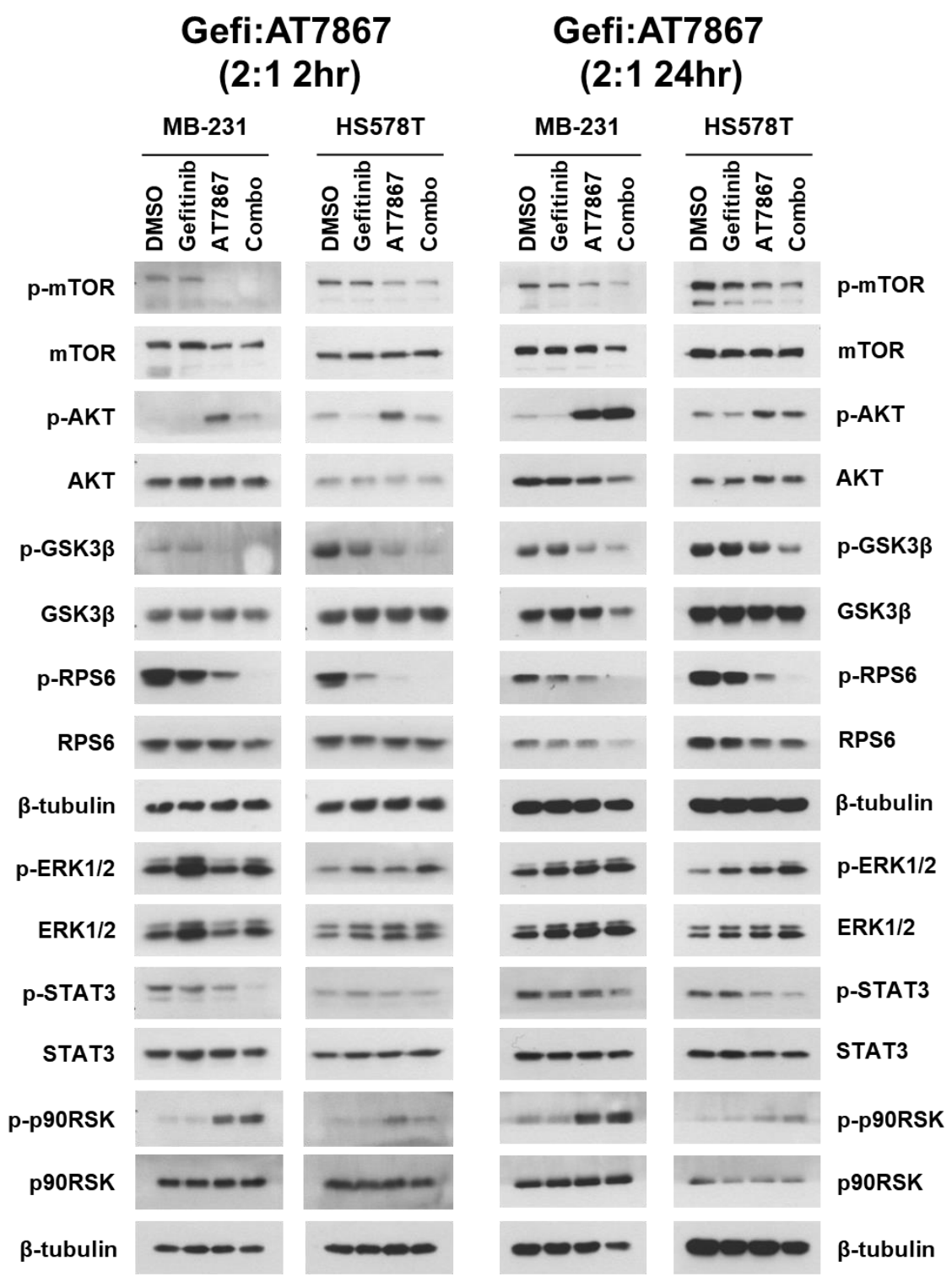

Figure 4. Cell signaling in Gefi+AT7867-treated TNBC cells. Cells were treated with different drug combinations for indicated times. Cell lysates were subjected to Western blot (Figure S1) analysis with antibodies for indicated proteins.

AT7867 reduced the levels of p-mTOR, p-GSK3 $\beta$, and p-RPS6 in these cells after $2 \mathrm{~h}$ of treatment. This suggests downregulation of the PI3K/AKT/mTOR/S6K pathway by AT7867. There were no significant effects on the levels of p-ERK1/2 and p-STAT3. Taken together, these results support the specificity of AT7867 and the anti-proliferative and anti-clonogenic effects of AT7867 on MSL TNBC cells (Figures 1 and 2). Surprisingly, the levels of p-AKT and p-p90RSK were upregulated by AT7867 in the cells treated for $2 \mathrm{~h}$. The reactivation of the PI3K or ERK pathway through the relief of the negative feedback loops in cancer cell lines, when treated with PI3K and/or mTOR inhibitors, has been well established [110-113]. A similar increase in p-AKT (S473) was reported in the glioblastoma cell line U87MG [43].

The Gefi+AT7867 treatment induced further changes in these cells, including the suppression of p-AKT (which was induced by AT7867), the near-complete suppression of p-GSK3 $\beta$ and p-RPS6, and the suppression of p-STAT3 (Figure 4, left). Most of these changes, except for the recurrence of p-AKT, were sustained after $24 \mathrm{~h}$ of treatment (Figure 4 , right). In addition, the levels of $\mathrm{p}$-ERK1/2 were increased. The levels of $\mathrm{p}$-RPS6, a major 
regulator of protein synthesis during cell cycle progression, were further reduced by $24 \mathrm{~h}$ of Gefi+AT7867 treatment; however, the reactivation of p-AKT and p-p90RSK, and the unregulated maintenance of p-ERK1/2, may contribute to the residual survival of TNBC cells under these conditions.

\subsection{Upregulation of the MEK/ERK Pathway by Gefitinib and AT7867}

Gefi+AT7867 enhanced the anti-proliferative and anti-clonogenic effects in MSL subtype TNBC cells; however, we hypothesized that additional signaling pathways may contribute to the residual survival of TNBC cells in the presence of Gefi+AT7867. For

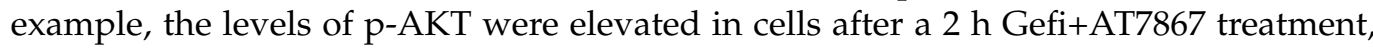
and were sustained to $24 \mathrm{~h}$ (Figure 4). In addition, p-p90RSK, a downstream target of the RAS/RAF/MEK/ERK pathway, was upregulated by AT7867 and Gefi+AT7867. No significant downregulation was observed in the levels of p-ERK1/2. Interestingly, the levels of p-ERK1/2 were slightly increased by Gefi+AT7867 in cells treated for $24 \mathrm{~h}$ (Figure 4, right).

To decipher the pathways that were upregulated in MSL type TNBC cells by Gefi+AT7867, we conducted an antibody microarray analysis. A proteomic expression analysis, comparing gefitinib alone and Gefi+AT7867, was further performed in the Kyoto Encyclopedia of Genes and Genomes (KEGG) pathways database. As a result, we identified that the MEK/ERK pathway was activated by Gefi+AT7867 when compared to gefitinib alone (Figure 5).

A

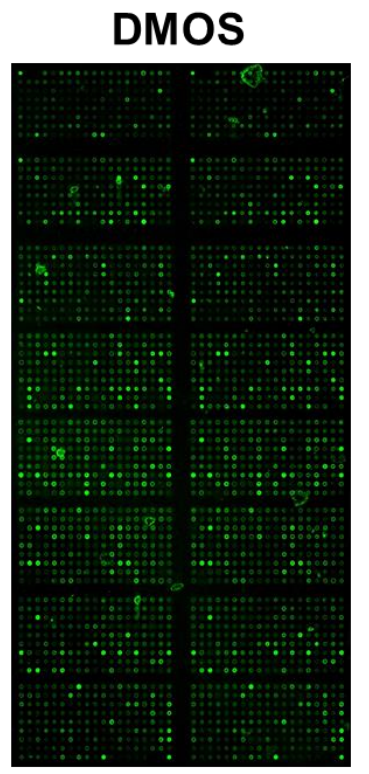

Gefitinib

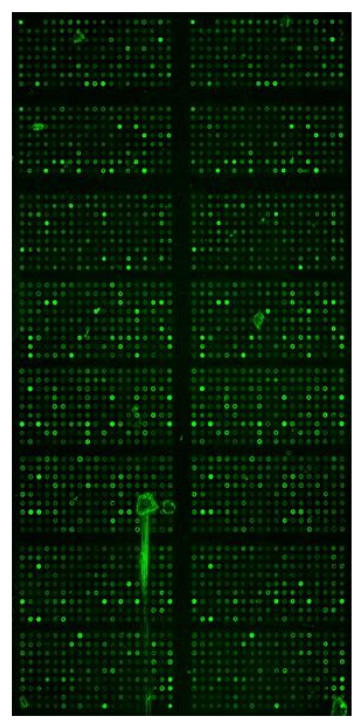

Combo

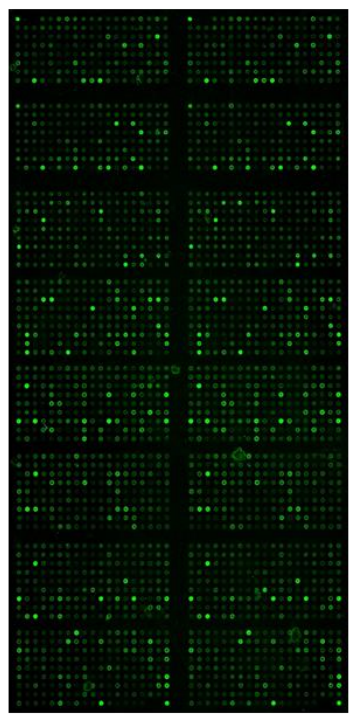

B
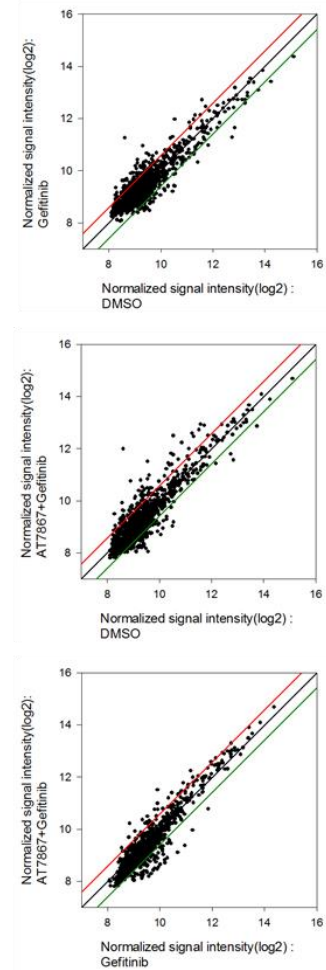

Figure 5. Cont. 


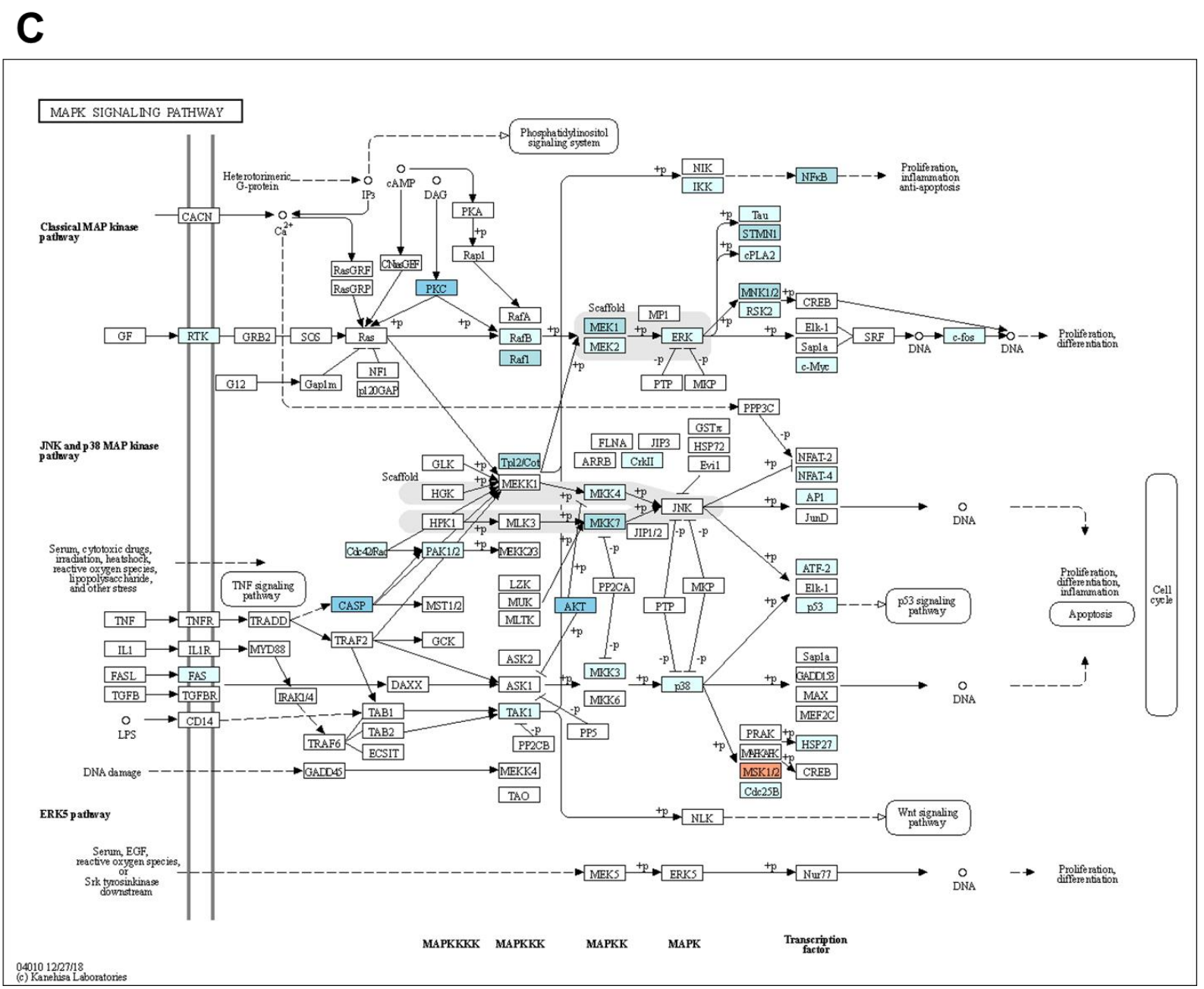

Figure 5. Antibody array analysis. (A) Fluorescence images of the antibody arrays. (B) Scatter plots of fluorescence signals; intensities of the control sample were plotted on the $\mathrm{x}$-axis, and intensities of the test sample were plotted on the $\mathrm{y}$-axis. Red and green lines indicate a 1.5-fold increase and decrease in fluorescence intensities, respectively, compared with the control sample. (C) The Kyoto Encyclopedia of Genes and Genomes (KEGG) pathway map for MAPK/ERK kinase (MEK)/extracellular signal-regulated kinase (ERK) pathway identified by antibody array analysis. Blue color indicates upregulated molecules. The KEGG pathway map was kindly provided by Kanehisa Laboratories (Kyoto University, Kyoto, Japan).

\subsection{Synergistic Enhancement of the Anti-Proliferative Effect of Gefitinib and AT7867 via the Inhibition of the MEK Pathway}

The antibody array analysis indicated activation of the MEK/ERK pathway by Gefi+AT7867; therefore, we performed a MTT screening with five MEK/ERK inhibitors (Table 1) in the presence of Gefi+AT7867 in MDA-MB-231 cells. These inhibitors included: (1) CI-1040 (PD184352), an ATP non-competitive MEK1/2 inhibitor (MEK1/2i) with an $\mathrm{IC}_{50}$ of $17 \mathrm{nM}$ in cell-based assays [55]; (2) U0126, a selective MEK1/2i with an IC $_{50}$ of $70 \mathrm{nM}$ and $60 \mathrm{nM}$ in biochemical assays [96]; (3) BIX 02189, a potent MEK5 inhibitor with an $\mathrm{IC}_{50}$ of $1.5 \mathrm{nM}$, which also inhibits ERK5 $\left(\mathrm{IC}_{50}=59 \mathrm{nM}\right)$ in biochemical assays and does not inhibit MEK1/2, ERK2, and c-Jun N-terminal kinase 2 (JNK2) [49]; (4) FR 180204, an ATP-competitive ERK inhibitor with an inhibitory constant (Ki) of 0.31 and $0.14 \mu \mathrm{M}$ for ERK1 and ERK2, respectively, in cell-free assays [61]; and (5) PD-0325901 (Mirdametinib), a selective non-ATP-competitive MEK1 $/ 2 \mathrm{i}\left(\mathrm{IC}_{50}=0.33 \mathrm{nM}\right.$ in cell-free assays) [75].

As shown in Figure 6A, PD-0325901 was the most potent MEKi to induce strong synergism with Gefi+AT7867 in MDA-MB-231 cells. Furthermore, the triple combination of gefitinib and AT7867 and PD-0325901 reduced MDA-MB-231 and HS578T cell viability (Figure 6B). 
B
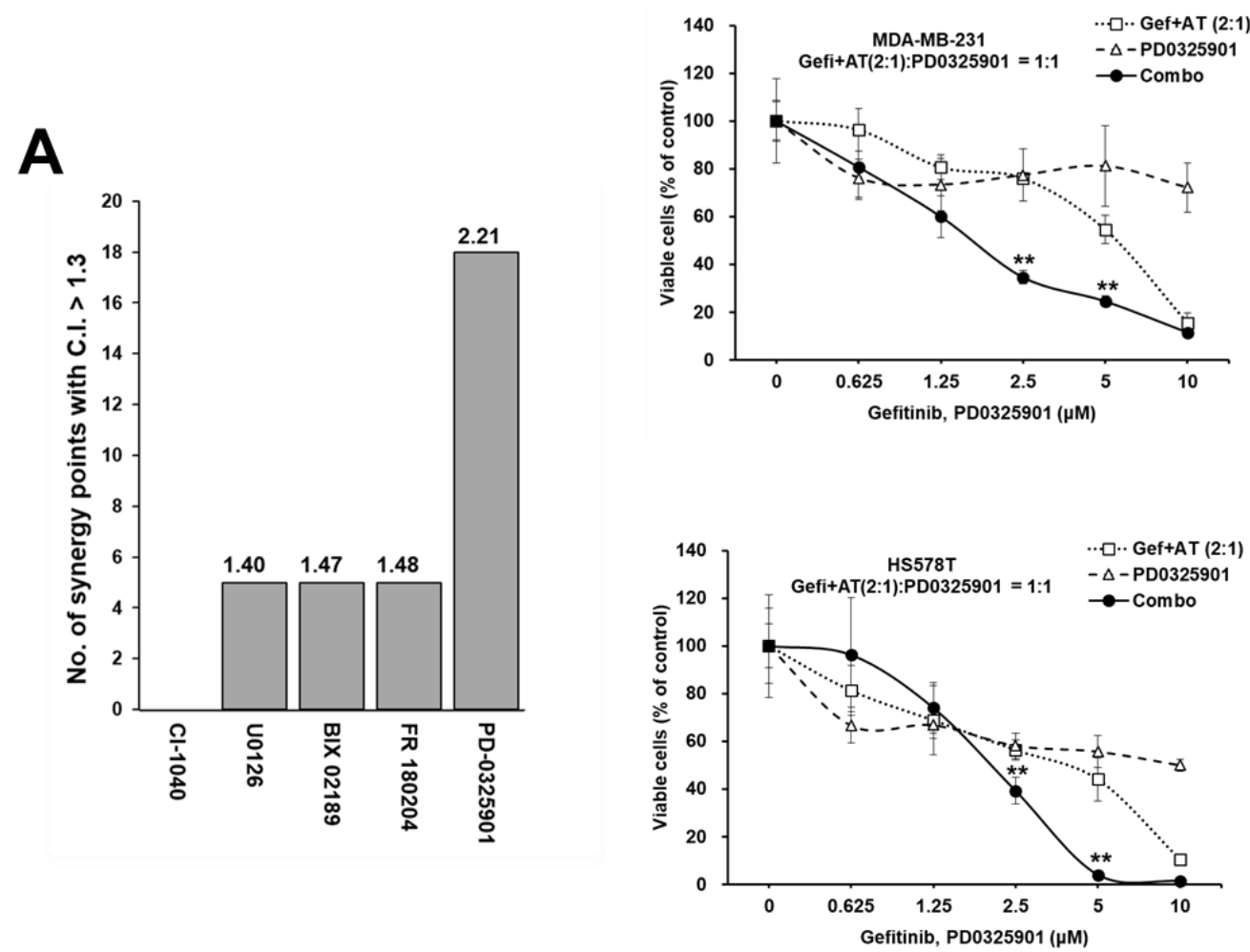

Figure 6. Synergistic anti-proliferative effect in TNBC cells via additional inhibition of the MEK/ERK pathway in the presence of Gefi+A7867. (A) Results of the MEK/ERK inhibitor screening with Gefi+AT7867 in MDA-MB-231 cells. The numbers of combination points with a CI $>1.3$ are depicted, and the numbers on the top of each bar are the mean CI values of the indicated drugs. (B) The combination effects of PD-0325901 in the presence of Gefi+AT7867 in two TNBC cells. Cells were treated with serially diluted concentrations of PD-0325901 in the presence of Gefi+AT7867 for $72 \mathrm{~h}$. Data represent mean \pm SD from at least three independent experiments performed in triplicate. ${ }^{* *} p<0.01$.

\subsection{Induction of Cell Death by Gefitinib and AT7867 and PD-0325901}

Treatment with Gefi+AT7867 for $72 \mathrm{~h}$ induced G1 arrest, but not cell death, in MDAMB-231 cells (Figure 2). Therefore, cell cycle distribution was analyzed in MDA-MB-231 cells treated with the triple drug combination for $24 \mathrm{~h}$ (Figure 7). Treatment with PD0325901 alone increased and reduced the G1 and S phase, respectively, when compared with the DMSO control (Figure 7C). There was no significant increase in the G1 phase with gefitinib (Figure 7B) or AT7867 (Figure 7E) treatment alone; however, the effects of PD-0325901 were sustained in the presence of gefitinib (Figure 7D). By contrast, the effects of PD-0325901 were limited in the presence of AT7867 (Figure 7G). However, the addition of PD-0325901 in the presence of Gefi+AT7867 produced a marked increase in the sub-G1 population (34.94\%; Figure $7 \mathrm{H})$. This increase is the result of an increase in apoptotic cells containing fractional DNA content [114-119]. Taken together, PD-0325901 induced apoptosis in the presence of Gefi+AT7867 after $24 \mathrm{~h}$, while no significant apoptosis was observed in the absence of PD-0325901 after $72 \mathrm{~h}$ treatment (Figure 2). 

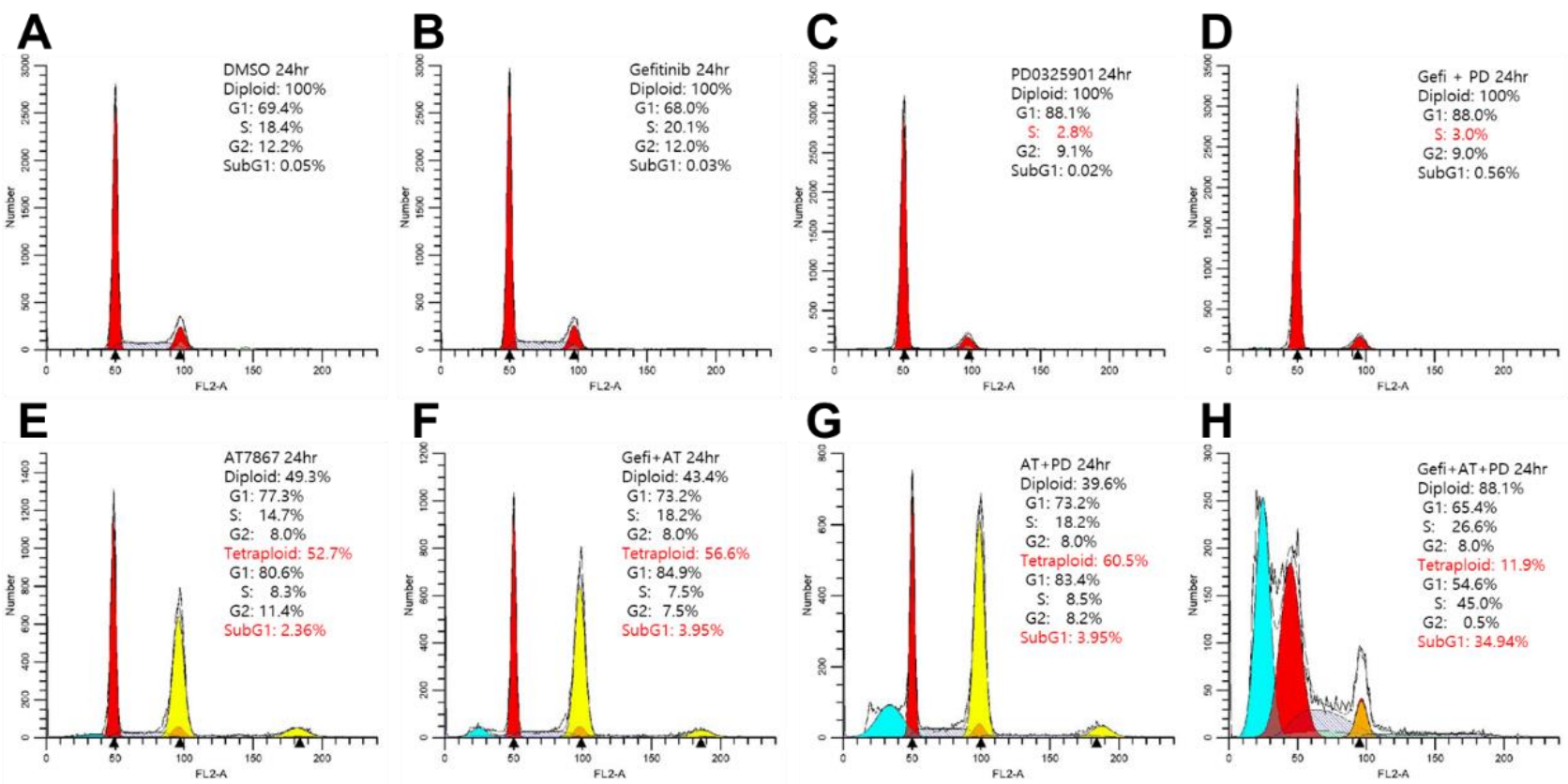

Figure 7. Cell cycle analysis of MDA-MB-231 cells treated with a triple combination of gefitinib and AT7867 and PD0326901(A-H). Representative histograms of cell cycle analysis in MDA-MB-231 cells in the presence of each drug or combinations of drugs as indicated. Abbreviations: AT, AT7867; Gefi, gefitinib; and PD-0325901.

\subsection{Blocking Long-Term Survival of TNBC Cells Using Gefitinib and AT7867 and PD-0326901}

The inhibition of the MEK/ERK pathway by PD-0325901 in MSL TNBC cells was analyzed by long-term colony formation assay. As a single agent, $10 \mu \mathrm{M}$ of gefitinib had little or no effect on MDA-MB-231 and HS578T colony formation (Figure 8). Treatment with $2.5 \mu \mathrm{M}$ of AT7867 differentially reduced the number of colonies in MDA-MB-231 and HS578T cells. Interestingly, HS578T cells were relatively more resistant to AT7867 than MDA-MB-231 cells (Figure 8B). PD-0325901 (10 $\mu \mathrm{M})$ alone markedly reduced the long-term survival of both MDA-MB-231 and HS578T cells; however, no significant synergism was observed following the gefitinib and PD-0325901 treatment. Contrarily, PD-0325901 further potentiated the effects of AT7867 in both cells. Moreover, the addition of PD-0325901 resulted in the near-complete inhibition of colony formation of both MSL type cells in the presence of gefitinib and AT7867 (Figure 8). These results suggest that this triple combination could further reduce the survival of residual cancer cells. 


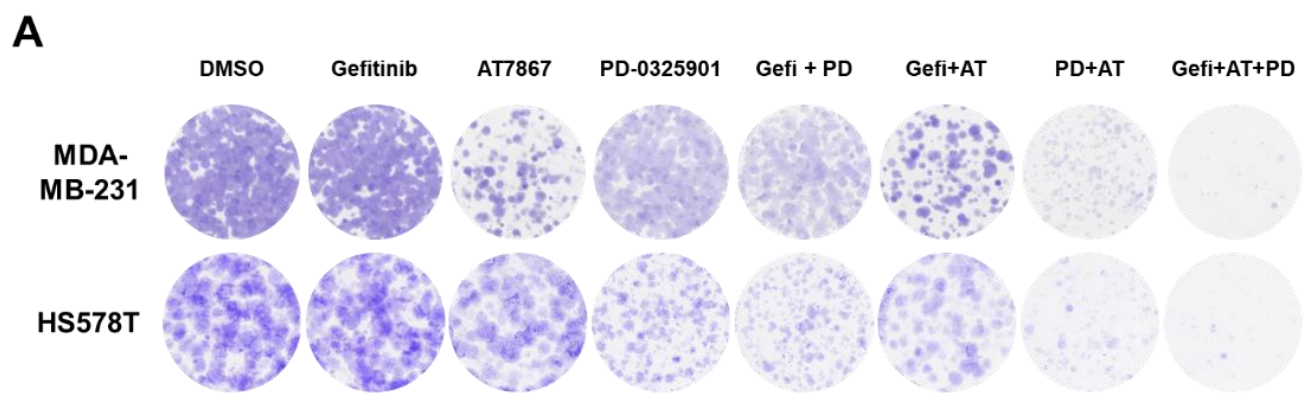

B

MDA-MB-231

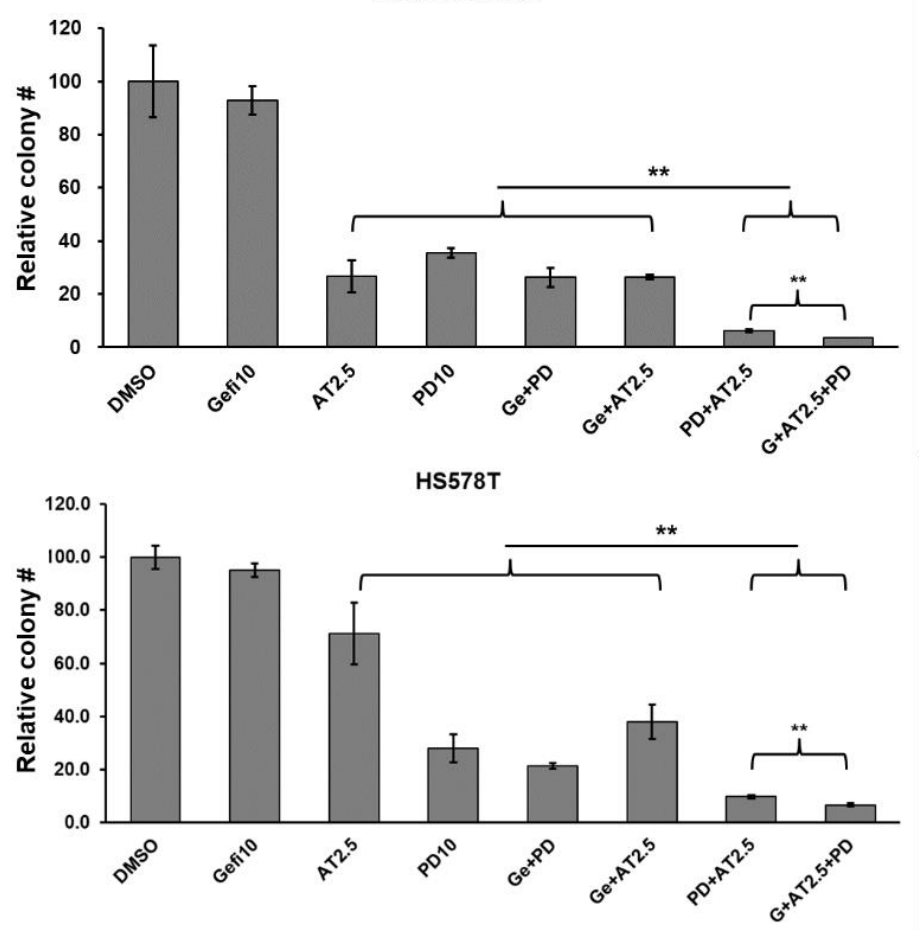

Figure 8. Reduced colony formation of MSL TNBC cells treated with gefitinib andAT7867 and PD-0326901. (A) Representative images of the colonies; cells were treated with $10 \mu \mathrm{M}$ of gefitinib, $2.5 \mu \mathrm{M}$ of AT7867, and $10 \mu \mathrm{M}$ of PD-0325901, or other drug combinations (as indicated) for $24 \mathrm{~h}$ and further cultivated for 10-14 days to form colonies in normal growth media. The surviving colonies were stained and scanned using an image scanner. Three independent experiments were performed in triplicate and representative images are shown. (B) Relative colony numbers were determined and presented as mean \pm SEM. ${ }^{* *} p<0.01$.

\subsection{Regulation of Signaling Pathways in TNBC Cells by Gefitinib and AT7867 and PD-0326901}

The effects of this triple combination on the signaling pathways were determined by Western blot analysis. MDA-MB-231 and HS578T cells were treated with drug combinations for $24 \mathrm{~h}$, and the cell lysates were analyzed (Figure 9). As expected, the addition of PD0325901 abolished the levels of p-ERK1/2 (lanes 3 and 4 in MDA-MB-231 and HS578T). The levels of p-RPS6 were further reduced by PD-0325901 in the presence of Gefi+AT7867. RPS6 was phosphorylated by S6K and RSK [109]; these results support that the inhibition of MEK by PD-0325901 reduces the residual phosphorylation of RPS6 via the MEK/ERK/RSK pathway. Importantly, PD-0325901 induced the cleavage of caspase-3. Inversely, the levels of the X-linked inhibitor of apoptosis protein (XIAP) were reduced by the gefitinib and AT7867 and PD-0326901 treatment. Previously, XIAP was reported as a causative protein in the acquired resistance of TNBC cells to the EGFR/HER2 inhibitor, GW583340 [120]. All these results are consistent with the cell cycle analysis results (Figure 7). Collectively, the 
addition of PD-0325901 induced the apoptotic cell death of MSL TNBC cells in the presence of Gefi+AT7867.

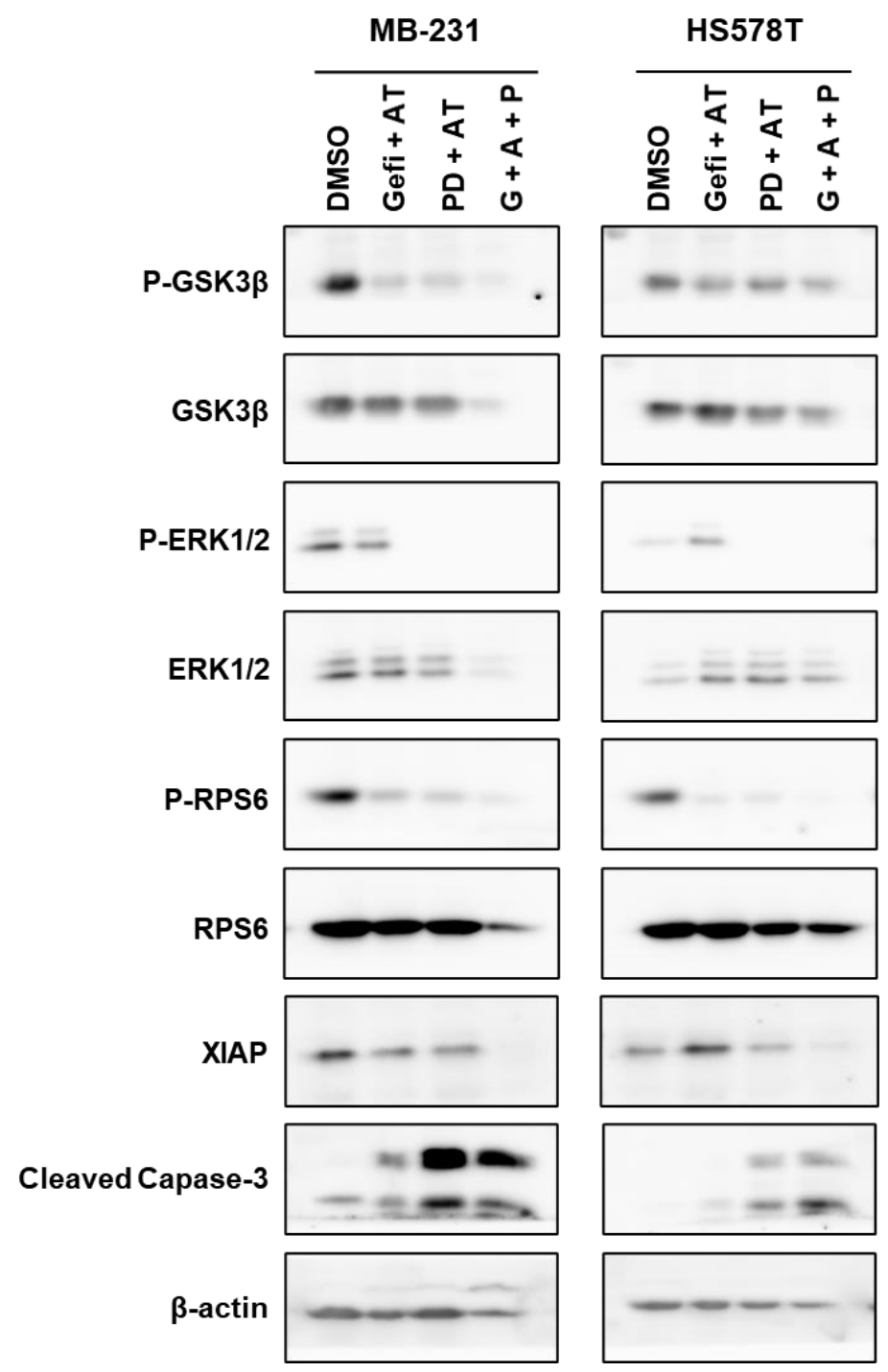

Figure 9. Western blot analysis of TNBC cells treated with different drug combinations (Figure S2). The cells were treated with drug combinations for $24 \mathrm{~h}$, and the cell lysates were resolved on SDS-PAGE and proved with antibodies for indicated proteins.

\section{Discussion}

High levels of EGFR expression in TNBC patients induces activation of the PI3K/AKT, MEK/ERK, and JAK/STAT3 pathways [17,121,122]. The MSL subtype of TNBC is associated with activated EGFR signaling [5] and exhibits greater intrinsic resistance to EGFRis than the BL TNBC cells $[25,30]$. Inhibition of EGFR alone does not suppress the proliferation of TNBC cells in preclinical cell line models; however, growing evidence supports EGFR as a potential therapeutic target for TNBC treatments, especially in combination with other targeted drugs $[3,25,30,33,37,123-127]$. Therefore, the identification of targets in combination with EGFRis provides an alternative strategy for developing an effective TNBC therapy because EGFR-targeting drugs have been approved [15,16]. Previously, our group reported that the inhibition of the PI3K/AKT [25], MET [30], or mTORC1 [33] pathways by small-molecule inhibitors induced the sensitization of TNBC cells to EGFRis.

Additional screening with small molecule PKIs in MDA-MB-231 cells identified AT7867 as a combination partner with gefitinib for MSL type TNBC cells. AT7867 is 
an ATP-competitive inhibitor of AKT1/2/3 ( $\mathrm{IC}_{50}=32,17,47 \mathrm{nM}$, respectively), p70S6K $\left(\mathrm{IC}_{50}=85 \mathrm{nM}\right)$, and PKA $\left(\mathrm{IC}_{50}=20 \mathrm{nM}\right)$ [43]. Interestingly, the PI3K/AKT $/ \mathrm{mTOR}$ pathway is activated in $10-21 \%$ of TNBCs [128]. Here, we showed that AT7867 potentiated the anti-proliferative effect of gefitinib and further reduced the colony formation of TNBC cells in the presence of gefitinib. However, Gefi+AT7867 did not induce apoptotic cell death in TNBC cells. Additionally, Gefi+AT7867 increased the activity of the MEK/ERK pathway. Therefore, we hypothesized that MEK/ERK activation may contribute to the survival of TNBC cells, even in the presence of Gefi+AT7867. In line with this, mutations of Kristen rat sarcoma viral oncogene homolog (KRAS), an upstream regulator of the MEK/ERK pathway, confer EGFRi resistance in lung adenocarcinoma [129].

Additional combination screening identified that PD-0325901 (Mirdametinib) induced apoptotic cell death in TNBC cells in the presence of Gefi+AT7867. The inhibition of Gefi+AT7867-induced p-ERK resulted in the induction of cleaved caspase- 3 and reduction in the expression of XIAP. Functionally, gefitinib + AT7867 + PD-0325901 markedly diminished the number of surviving colonies. Taken together, attenuating the Gefi+AT7867induced activation of the MEK/ERK pathway via MEKi overcame resistance to EGFRi (Figure 10). This reduced the survival of residual TNBC cells.

The expression of ERK1/2 is associated with that of EGFR in TNBC tissues [130], and high-level expression of ERK2 is correlated with shorter survival in TNBC patients [131,132]. The RAS/RAF/MEK/ERK pathway is activated by amplification in TNBC, providing potential therapeutic targets [133,134]. Potential anti-proliferative effects of ERK inhibition in TNBC cells have been suggested [135-137]. Additionally, kinome analysis has revealed that MEK1/2 inhibition by selumentinib (AZD6244) causes acute loss of ERK activity, leading to the time-dependent reprogramming of receptor tyrosine kinases (RTKs) including platelet-derived growth factor receptor beta (PDGFR $\beta$ ), discoidin domain receptor tyrosine kinase 1/2 (DDR1/2), and AXL receptor tyrosine kinase (AXL), through ERK-dependent cellular myelocytomatosis (c-Myc) degradation in TNBC cell lines, SUM159 and MDAMB-231 [138]. These RTK stimulations overcame MEK2 inhibition and reactivated the RAF/MEK2/ERK1/RSK1 pathway, which eventually circumvented MEK inhibition. Dual inhibition strategies have been evaluated for MEKi with other kinase inhibitors to treat TNBC in preclinical models, including EGFRi [32], PI3Ki, PDGFRi [139], and dasatinib [140]. However, phase 2 clinical trials with combination treatments involving the MEKi, trametinib (GSK120212), and the AKTi, uprosertib (GSK2141795), have shown limited efficacy in 50 patients with advanced TNBC [141].

In this report, we found that the triple combination of EGFRi + AKTi + MEKi is more effective at inducing apoptosis and eliminating residual colonies of MSL subtype TNBC cells in vitro. Previous studies suggested that blocking single- or double-signaling pathways was not sufficient to inhibit and induce TNBC cell proliferation and apoptosis, respectively $[25,30,33]$. This might be because multiple compensatory pathways support the survival of TNBC. In addition, drug-induced reprograming of survival pathways is required to circumvent drug resistance. Further explorations into multiplex drug combinations may provide new insights on treating intractable TNBC. 


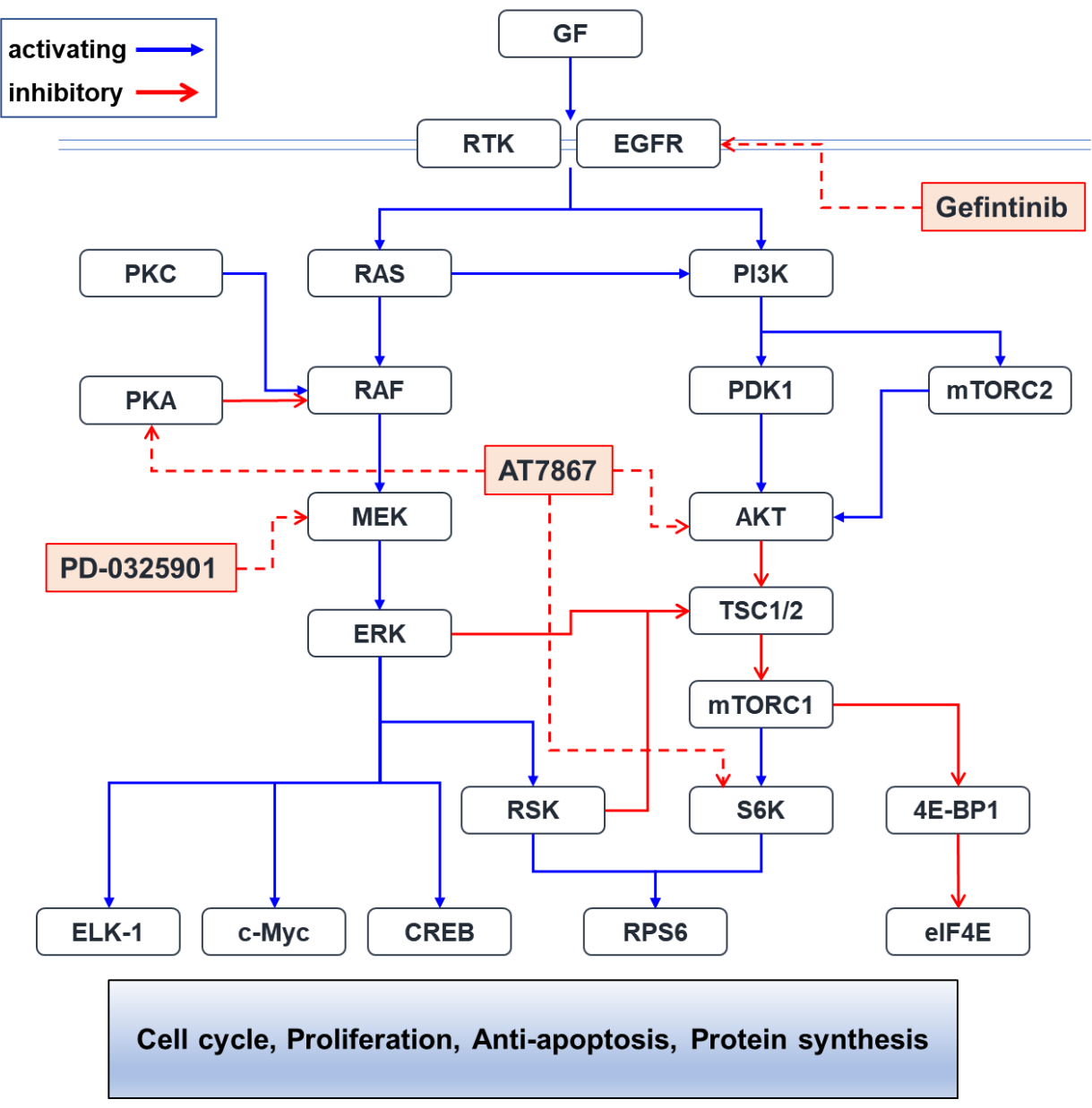

Figure 10. Putative Pathways affected by small-molecule inhibitors in this study. The PI3K/AKT/mTORC1 and RAS/RAF/MEK/ERK pathways cross-talk each other. Small-molecule PKIs used in this study would inhibit their target molecules, which results in synergistic anti-cancer effects. Abbreviations: 4E-BP1, eukaryotic initiation factor 4E-binding protein 1; AKT, v-akt murine thymoma viral oncogene homolog; c-Myc, cellular myelocytomatosis; CREB, cAMP responsive element-binding protein; EGFR, epidermal growth factor receptor; eIF4E, eukaryotic translation initiation factor 4E; ELK-1, E twenty-six (ETS) like-1; ERK, extracellular signal-regulated kinase; GF, growth factor; MEK, MAPK/ERK kinase; mTORC1/2, mammalian target of rapamycin complex 1/2; PDK1, 3-phosphoinositide-dependent protein kinase-1; PI3K, phosphoinositide 3-kinase; PKA, protein kinase A; PKC, protein kinase C; RAF, v-raf-1 murine leukemia viral oncogene homolog; RAS, rat sarcoma; RPS6, ribosomal protein S6; RSK, ribosomal S6 kinase; RTK, receptor tyrosine kinase; S6K, S6 kinase; TSC1/2, Tuberous sclerosis $1 / 2$.

\section{Conclusions}

In this report, we found that the triple combination of EGFRi + AKTi + MEKi is more effective at inducing apoptosis and eliminating residual colonies of MSL subtype TNBC cells in vitro. Previous studies have suggested that blocking single- or double-signaling pathways is not sufficient to inhibit and induce TNBC cell proliferation and apoptosis, respectively $[25,30,33]$. This might be because multiple compensatory pathways support the survival of TNBC. In addition, drug-induced reprograming of survival pathways is required to circumvent drug resistance. Further explorations.

Supplementary Materials: The following are available online at https:/ / www.mdpi.com/2072-669 4/13/6/1205/s1, Figure S1: uncropped blot images for Figure 4, Figure S2: uncropped blot images for Figure 9.

Author Contributions: Conceptualization, Y.W.Y. and Y.-S.S.; methodology, K.S.Y., Y.W.Y., J.C. and Y.-S.S.; investigation, K.S.Y., Y.W.Y., J.C. and Y.-S.S.; data curation, K.S.Y., Y.W.Y., J.C. and Y.-S.S.; 
writing-original draft preparation, Y.W.Y. and Y.-S.S.; writing—review and editing, K.S.Y., Y.W.Y., J.C. and Y.-S.S.; visualization, Y.W.Y. and Y.-S.S.; supervision, Y.-S.S.; project administration, K.S.Y.; funding acquisition, J.C. and Y.-S.S. All authors have read and agreed to the published version of the manuscript.

Funding: This work was supported by the National Research Foundation of Korea (NRF) grants funded by the Korea Mistry of Science and ICT (MSIT): NRF-2015R1D1A1A01057893 (Y.-S.S.), NRF 2018R1D1A1B070489 (Y.-S.S.), and NRF-2019R1A4A1028268 (J.C. and Y.-S.S.).

Institutional Review Board Statement: Not applicable.

Informed Consent Statement: Not applicable.

Data Availability Statement: Data in this study will be available from the corresponding authors upon reasonable request.

Conflicts of Interest: The authors declare no conflict of interest.

\section{References}

1. Diaz, L.K.; Cryns, V.L.; Symmans, W.F.; Sneige, N. Triple Negative Breast Carcinoma and the Basal Phenotype\&colon; From Expression Profiling to Clinical Practice. Adv. Anat. Pathol. 2007, 14, 419-430. [CrossRef] [PubMed]

2. Huynh, M.; Pambid, M.R.; Jayanthan, A.; Dorr, A.; Los, G.; Dunn, S.E. The Dawn of Targeted Therapies for Triple Negative Breast Cancer (TNBC): A Snapshot of Investigational Drugs in Phase I and II Trials. Expert Opin. Investig. Drug 2020, 29, 1199-1208. [CrossRef]

3. Nakai, K.; Hung, M.-C.; Yamaguchi, H. A Perspective on Anti-EGFR Therapies Targeting Triple-Negative Breast Cancer. Am. J. Cancer Res. 2016, 6, 1609-1623. [PubMed]

4. Brenton, J.D.; Carey, L.A.; Ahmed, A.A.; Caldas, C. Molecular Classification and Molecular Forecasting of Breast Cancer: Ready for Clinical Application? J. Clin. Oncol. 2005, 23, 7350-7360. [CrossRef]

5. Lehmann, B.D.; Bauer, J.A.; Chen, X.; Sanders, M.E.; Chakravarthy, A.B.; Shyr, Y.; Pietenpol, J.A. Identification of Human Triple-Negative Breast Cancer Subtypes and Preclinical Models for Selection of Targeted Therapies. J. Clin. Investig. 2011, 121, 2750-2767. [CrossRef] [PubMed]

6. Lehmann, B.D.; Pietenpol, J.A. Identification and Use of Biomarkers in Treatment Strategies for Triple-negative Breast Cancer Subtypes. J. Pathol. 2014, 232, 142-150. [CrossRef]

7. Liedtke, C.; Mazouni, C.; Hess, K.R.; André, F.; Tordai, A.; Mejia, J.A.; Symmans, W.F.; Gonzalez-Angulo, A.M.; Hennessy, B.; Green, M.; et al. Response to Neoadjuvant Therapy and Long-Term Survival in Patients With Triple-Negative Breast Cancer. J. Clin. Oncol. 2008, 26, 1275-1281. [CrossRef]

8. Kassam, F.; Enright, K.; Dent, R.; Dranitsaris, G.; Myers, J.; Flynn, C.; Fralick, M.; Kumar, R.; Clemons, M. Survival Outcomes for Patients with Metastatic Triple-Negative Breast Cancer: Implications for Clinical Practice and Trial Design. Clin. Breast Cancer 2009, 9, 29-33. [CrossRef]

9. Costa, R.; Shah, A.N.; Santa-Maria, C.A.; Cruz, M.R.; Mahalingam, D.; Carneiro, B.A.; Chae, Y.K.; Cristofanilli, M.; Gradishar, W.J.; Giles, F.J. Targeting Epidermal Growth Factor Receptor in Triple Negative Breast Cancer: New Discoveries and Practical Insights for Drug Development. Cancer Treat. Rev. 2017, 53, 111-119. [CrossRef]

10. Dent, R.; Trudeau, M.; Pritchard, K.I.; Hanna, W.M.; Kahn, H.K.; Sawka, C.A.; Lickley, L.A.; Rawlinson, E.; Sun, P.; Narod, S.A. Triple-Negative Breast Cancer: Clinical Features and Patterns of Recurrence. Clin. Cancer Res. 2007, 13, 4429-4434. [CrossRef]

11. Yi, Y.W.; Kang, H.J.; Kim, H.J.; Kong, Y.; Brown, M.M.; Bae, I. Targeting Mutant P53 by a SIRT1 Activator YK-3-237 Inhibits the Proliferation of Triple-Negative Breast Cancer Cells. Oncotarget 2013, 4, 984-994. [CrossRef] [PubMed]

12. Hou, S.; Yi, Y.W.; Kang, H.J.; Zhang, L.; Kim, H.J.; Kong, Y.; Liu, Y.; Wang, K.; Kong, H.-S.; Grindrod, S.; et al. Novel Carbazole Inhibits Phospho-STAT3 through Induction of Protein-Tyrosine Phosphatase PTPN6. J. Med. Chem. 2014, 57, 6342-6353. [CrossRef]

13. Kang, H.J.; Yi, Y.W.; Hou, S.-J.; Kim, H.J.; Kong, Y.; Bae, I.; Brown, M.L. Disruption of STAT3-DNMT1 Interaction by SH-I-14 Induces Re-Expression of Tumor Suppressor Genes and Inhibits Growth of Triple-Negative Breast Tumor. Oncotarget 2014, 5, 83457-83468. [CrossRef]

14. Eccles, S.A. The Epidermal Growth Factor Receptor/Erb-B/HER Family in Normal and Malignant Breast Biology. Int. J. Dev. Biol. 2011, 55, 685-696. [CrossRef]

15. Yarden, Y.; Pines, G. The ERBB Network: At Last, Cancer Therapy Meets Systems Biology. Nat. Rev. Cancer 2012, 12, 553-563. [CrossRef] [PubMed]

16. Wheeler, D.L.; Dunn, E.F.; Harari, P.M. Understanding Resistance to EGFR Inhibitors-Impact on Future Treatment Strategies. Nat. Rev. Clin. Oncol. 2010, 7, 493-507. [CrossRef] [PubMed]

17. Wee, P.; Wang, Z. Epidermal Growth Factor Receptor Cell Proliferation Signaling Pathways. Cancers 2017, 9, 52. [CrossRef]

18. Zulkifli, A.A.; Tan, F.H.; Putoczki, T.L.; Stylli, S.S.; Luwor, R.B. STAT3 Signaling Mediates Tumour Resistance to EGFR Targeted Therapeutics. Mol. Cell Endocrinol. 2017, 451, 15-23. [CrossRef] 
19. Yarden, Y.; Sliwkowski, M.X. Untangling the ErbB Signalling Network. Nat. Rev. Mol. Cell Biol. 2001, 2, 127-137. [CrossRef] [PubMed]

20. Arteaga, C.L.; Truica, C.I. Challenges in the Development of Anti-Epidermal Growth Factor Receptor Therapies in Breast Cancer. Semin. Oncol. 2004, 31, 3-8. [CrossRef]

21. Hong, Y.B.; Kim, J.S.; Yi, Y.W.; Seong, Y.-S.; Bae, I. Exploring Protein Kinase Inhibitors: Potentiating Gemcitabine Efficacy in Pancreatic Cancer. Pancreas 2012, 41, 496-498. [CrossRef] [PubMed]

22. Kim, Y.J.; Hong, Y.B.; Cho, C.H.; Seong, Y.-S.; Bae, I. Exploring Protein Kinase Inhibitors: Unveiling Gemcitabine Resistance in Pancreatic Cancer. Pancreas 2012, 41, 804-805. [CrossRef]

23. Duong, H.; Hong, Y.B.; Kim, J.S.; Lee, H.; Yi, Y.W.; Kim, Y.J.; Wang, A.; Zhao, W.; Cho, C.H.; Seong, Y.; et al. Inhibition of Checkpoint Kinase 2 (CHK2) Enhances Sensitivity of Pancreatic Adenocarcinoma Cells to Gemcitabine. J. Cell Mol. Med. 2013, 17, 1261-1270. [CrossRef]

24. Yi, Y.W.; Kang, H.J.; Kim, H.J.; Hwang, J.S.; Wang, A.; Bae, I. Inhibition of Constitutively Activated Phosphoinositide 3kinase/AKT Pathway Enhances Antitumor Activity of Chemotherapeutic Agents in Breast Cancer Susceptibility Gene 1-defective Breast Cancer Cells. Mol. Carcinog. 2013, 52, 667-675. [CrossRef]

25. Yi, Y.W.; Hong, W.; Kang, H.J.; Kim, H.J.; Zhao, W.; Wang, A.; Seong, Y.; Bae, I. Inhibition of the PI3K/AKT Pathway Potentiates Cytotoxicity of EGFR Kinase Inhibitors in Triple-negative Breast Cancer Cells. J. Cell Mol. Med. 2013, 17, 648-656. [CrossRef] [PubMed]

26. Duong, H.-Q.; Yi, Y.W.; Kang, H.J.; Bae, I.; Jang, Y.-J.; Kwak, S.-J.; Seong, Y.-S. Combination of Dasatinib and Gemcitabine Reduces the ALDH1A1 Expression and the Proliferation of Gemcitabine-Resistant Pancreatic Cancer MIA PaCa-2 Cells. Int. J. Oncol. 2014, 44, 2132-2138. [CrossRef]

27. Duong, H.-Q.; Yi, Y.W.; Kang, H.J.; Hong, Y.B.; Tang, W.; Wang, A.; Seong, Y.-S.; Bae, I. Inhibition of NRF2 by PIK-75 Augments Sensitivity of Pancreatic Cancer Cells to Gemcitabine. Int. J. Oncol. 2013, 44, 959-969. [CrossRef]

28. Cao, J.; Heijkants, R.C.; Jochemsen, A.G.; Dogrusöz, M.; de Lange, M.J.; van der Velden, P.A.; van der Burg, S.H.; Jager, M.J.; Verdijk, R.M. Targeting of the MAPK and AKT Pathways in Conjunctival Melanoma Shows Potential Synergy. Oncotarget 2014, 5, 58021-58036. [CrossRef]

29. Yi, Y.W.; Park, J.-S.; Kwak, S.-J.; Seong, Y.-S. Co-Treatment with BEZ235 Enhances Sensitivity of BRCA1-Negative Breast Cancer Cells to Olaparib. Anticancer Res. 2015, 35, 3829-3838.

30. Yi, Y.W.; You, K.; Bae, E.J.; Kwak, S.-J.; Seong, Y.-S.; Bae, I. Dual Inhibition of EGFR and MET Induces Synthetic Lethality in Triple-Negative Breast Cancer Cells through Downregulation of Ribosomal Protein S6. Int. J. Oncol. 2015, 47, 122-132. [CrossRef] [PubMed]

31. Ayub, A.; Yip, W.K.; Seow, H.F. Dual Treatments Targeting IGF-1R, PI3K, MTORC or MEK Synergize to Inhibit Cell Growth, Induce Apoptosis, and Arrest Cell Cycle at G1 Phase in MDA-MB-231 Cell Line. Biomed. Pharmacother. 2015, 75, 40-50. [CrossRef]

32. Maiello, M.R.; D'Alessio, A.; Bevilacqua, S.; Gallo, M.; Normanno, N.; Luca, A.D. EGFR and MEK Blockade in Triple Negative Breast Cancer Cells. J. Cell Biochem. 2015, 116, 2778-2785. [CrossRef]

33. You, K.S.; Yi, Y.W.; Kwak, S.-J.; Seong, Y.-S. Inhibition of RPTOR Overcomes Resistance to EGFR Inhibition in Triple-Negative Breast Cancer Cells. Int. J. Oncol. 2018, 52, 828-840. [CrossRef] [PubMed]

34. He, J.; McLaughlin, R.P.; van der Noord, V.; Foekens, J.A.; Martens, J.W.M.; van Westen, G.; Zhang, Y.; van de Water, B. MultiTargeted Kinase Inhibition Alleviates MTOR Inhibitor Resistance in Triple-Negative Breast Cancer. Breast Cancer Res. Treat. 2019, 178, 263-274. [CrossRef]

35. Bajor, M.; Graczyk-Jarzynka, A.; Marhelava, K.; Kurkowiak, M.; Rahman, A.; Aura, C.; Russell, N.; Zych, A.O.; Firczuk, M.; Winiarska, M.; et al. Triple Combination of Ascorbate, Menadione and the Inhibition of Peroxiredoxin-1 Produces Synergistic Cytotoxic Effects in Triple-Negative Breast Cancer Cells. Antioxidants 2020, 9, 320. [CrossRef]

36. Pattarawat, P.; Wallace, S.; Pfisterer, B.; Odoi, A.; Wang, H.-C.R. Formulation of a Triple Combination Gemcitabine plus Romidepsin + Cisplatin Regimen to Efficaciously and Safely Control Triple-Negative Breast Cancer Tumor Development. Cancer Chemother. Pharmacol. 2020, 85, 141-152. [CrossRef]

37. Ahmad, S.; He, Q.; Williams, K.P.; Scott, J.E. Identification of a Triple Drug Combination That Is Synergistically Cytotoxic for Triple-Negative Breast Cancer Cells Using a Novel Combination Discovery Approach. SLAS Discov. 2020, 25, 923-938. [CrossRef]

38. Kim, D.-J.; Yi, Y.-W.; Kim, J.H. In Situ Monitoring of Bindings between Dasatinib and Its Target Protein Kinases Using Magnetic Nanoparticles in Live Cells. J. Am. Chem. Soc. 2008, 130, 16466-16467. [CrossRef]

39. Minkovsky, N.; Berezov, A. BIBW-2992, a Dual Receptor Tyrosine Kinase Inhibitor for the Treatment of Solid Tumors. Curr. Opin. Investig. Drugs Lond. Engl. 2000 2008, 9, 1336-1346.

40. Yamaguchi, T.; Kakefuda, R.; Tajima, N.; Sowa, Y.; Sakai, T. Antitumor Activities of JTP-74057 (GSK1120212), a Novel MEK1/2 Inhibitor, on Colorectal Cancer Cell Lines in Vitro and in Vivo. Int. J. Oncol. 2011, 39, 23-31. [CrossRef]

41. Kim, S.I.; Kim, H.J.; Lee, H.-J.; Lee, K.; Hong, D.; Lim, H.; Cho, K.; Jung, N.; Yi, Y.W. Application of a Non-Hazardous Vital Dye for Cell Counting with Automated Cell Counters. Anal. Biochem. 2016, 492, 8-12. [CrossRef] [PubMed]

42. Cool, B.; Zinker, B.; Chiou, W.; Kifle, L.; Cao, N.; Perham, M.; Dickinson, R.; Adler, A.; Gagne, G.; Iyengar, R.; et al. Identification and Characterization of a Small Molecule AMPK Activator That Treats Key Components of Type 2 Diabetes and the Metabolic Syndrome. Cell Metab. 2006, 3, 403-416. [CrossRef] [PubMed] 
43. Grimshaw, K.M.; Hunter, L.-J.K.; Yap, T.A.; Heaton, S.P.; Walton, M.I.; Woodhead, S.J.; Fazal, L.; Reule, M.; Davies, T.G.; Seavers, L.C.; et al. AT7867 Is a Potent and Oral Inhibitor of AKT and P70 S6 Kinase That Induces Pharmacodynamic Changes and Inhibits Human Tumor Xenograft Growth. Mol. Cancer Ther. 2010, 9, 1100-1110. [CrossRef] [PubMed]

44. Howard, S.; Berdini, V.; Boulstridge, J.A.; Carr, M.G.; Cross, D.M.; Curry, J.; Devine, L.A.; Early, T.R.; Fazal, L.; Gill, A.L.; et al. Fragment-Based Discovery of the Pyrazol-4-Y1 Urea (AT9283), a Multitargeted Kinase Inhibitor with Potent Aurora Kinase Activity. J. Med. Chem. 2009, 52, 379-388. [CrossRef] [PubMed]

45. Yang, J.; Ikezoe, T.; Nishioka, C.; Tasaka, T.; Taniguchi, A.; Kuwayama, Y.; Komatsu, N.; Bandobashi, K.; Togitani, K.; Koeffler, H.P.; et al. AZD1152, a Novel and Selective Aurora B Kinase Inhibitor, Induces Growth Arrest, Apoptosis, and Sensitization for Tubulin Depolymerizing Agent or Topoisomerase II Inhibitor in Human Acute Leukemia Cells in Vitro and in Vivo. Blood 2007, 110, 2034-2040. [CrossRef]

46. Derenzini, E.; Lemoine, M.; Buglio, D.; Katayama, H.; Ji, Y.; Davis, R.E.; Sen, S.; Younes, A. The JAK Inhibitor AZD1480 Regulates Proliferation and Immunity in Hodgkin Lymphoma. Blood Cancer J. 2011, 1, e46. [CrossRef]

47. Steegmaier, M.; Hoffmann, M.; Baum, A.; Lénárt, P.; Petronczki, M.; Krššák, M.; Gürtler, U.; Garin-Chesa, P.; Lieb, S.; Quant, J.; et al. BI 2536, a Potent and Selective Inhibitor of Polo-like Kinase 1, Inhibits Tumor Growth In Vivo. Curr. Biol. 2007, 17, 316-322. [CrossRef] [PubMed]

48. Chen, L.; Yap, J.L.; Yoshioka, M.; Lanning, M.E.; Fountain, R.N.; Raje, M.; Scheenstra, J.A.; Strovel, J.W.; Fletcher, S. BRD4 Structure-Activity Relationships of Dual PLK1 Kinase/BRD4 Bromodomain Inhibitor BI-2536. ACS Med. Chem. Lett. 2015, 6, 764-769. [CrossRef] [PubMed]

49. Tatake, R.J.; O’Neill, M.M.; Kennedy, C.A.; Wayne, A.L.; Jakes, S.; Wu, D.; Kugler, S.Z.; Kashem, M.A.; Kaplita, P.; Snow, R.J. Identification of Pharmacological Inhibitors of the MEK5/ERK5 Pathway. Biochem. Biophys. Res. Commun. 2008, 377, 120-125. [CrossRef] [PubMed]

50. Zhou, G.; Myers, R.; Li, Y.; Chen, Y.; Shen, X.; Fenyk-Melody, J.; Wu, M.; Ventre, J.; Doebber, T.; Fujii, N.; et al. Role of AMP-Activated Protein Kinase in Mechanism of Metformin Action. J. Clin. Investig. 2001, 108, 1167-1174. [CrossRef]

51. Boschelli, D.H.; Ye, F.; Wang, Y.D.; Dutia, M.; Johnson, S.L.; Wu, B.; Miller, K.; Powell, D.W.; Yaczko, D.; Young, M.; et al. Optimization of 4-Phenylamino-3-Quinolinecarbonitriles as Potent Inhibitors of Src Kinase Activity. J. Med. Chem. 2001, 44, 3965-3977. [CrossRef]

52. Golas, J.M.; Arndt, K.; Etienne, C.; Lucas, J.; Nardin, D.; Gibbons, J.; Frost, P.; Ye, F.; Boschelli, D.H.; Boschelli, F. SKI-606, a 4-Anilino-3-Quinolinecarbonitrile Dual Inhibitor of Src and Abl Kinases, Is a Potent Antiproliferative Agent against Chronic Myelogenous Leukemia Cells in Culture and Causes Regression of K562 Xenografts in Nude Mice. Cancer Res. 2003, 63, 375-381.

53. Chan, S.-L.; Lee, M.C.; Tan, K.O.; Yang, L.-K.; Lee, A.S.Y.; Flotow, H.; Fu, N.Y.; Butler, M.S.; Soejarto, D.D.; Buss, A.D.; et al. Identification of Chelerythrine as an Inhibitor of BclXL Function. J. Biol. Chem. 2003, 278, 20453-20456. [CrossRef]

54. Ring, D.B.; Johnson, K.W.; Henriksen, E.J.; Nuss, J.M.; Goff, D.; Kinnick, T.R.; Ma, S.T.; Reeder, J.W.; Samuels, I.; Slabiak, T.; et al. Selective Glycogen Synthase Kinase 3 Inhibitors Potentiate Insulin Activation of Glucose Transport and Utilization In Vitro and In Vivo. Diabetes 2003, 52, 588-595. [CrossRef]

55. Sebolt-Leopold, J.S.; Dudley, D.T.; Herrera, R.; Becelaere, K.V.; Wiland, A.; Gowan, R.C.; Tecle, H.; Barrett, S.D.; Bridges, A.; Przybranowski, S.; et al. Blockade of the MAP Kinase Pathway Suppresses Growth of Colon Tumors in Vivo. Nat. Med. 1999, 5, 810-816. [CrossRef]

56. Changelian, P.S.; Flanagan, M.E.; Ball, D.J.; Kent, C.R.; Magnuson, K.S.; Martin, W.H.; Rizzuti, B.J.; Sawyer, P.S.; Perry, B.D.; Brissette, W.H.; et al. Prevention of Organ Allograft Rejection by a Specific Janus Kinase 3 Inhibitor. Science 2003, 302, 875-878. [CrossRef] [PubMed]

57. Wang, S.; Midgley, C.A.; Scaërou, F.; Grabarek, J.B.; Griffiths, G.; Jackson, W.; Kontopidis, G.; McClue, S.J.; McInnes, C.; Meades, C.; et al. Discovery of N-Phenyl-4-(Thiazol-5-Yl)Pyrimidin-2-Amine Aurora Kinase Inhibitors. J. Med. Chem. 2010, 53, 4367-4378. [CrossRef] [PubMed]

58. Carpinelli, P.; Ceruti, R.; Giorgini, M.L.; Cappella, P.; Gianellini, L.; Croci, V.; Degrassi, A.; Texido, G.; Rocchetti, M.; Vianello, P.; et al. PHA-739358, a Potent Inhibitor of Aurora Kinases with a Selective Target Inhibition Profile Relevant to Cancer. Mol. Cancer Ther. 2007, 6, 3158-3168. [CrossRef]

59. Graff, J.R.; McNulty, A.M.; Hanna, K.R.; Konicek, B.W.; Lynch, R.L.; Bailey, S.N.; Banks, C.; Capen, A.; Goode, R.; Lewis, J.E.; et al. The Protein Kinase C $\beta$-Selective Inhibitor, Enzastaurin (LY317615.HCl), Suppresses Signaling through the AKT Pathway, Induces Apoptosis, and Suppresses Growth of Human Colon Cancer and Glioblastoma Xenografts. Cancer Res. 2005, 65, 7462-7469. [CrossRef]

60. Ono-Saito, N.; Niki, I.; Hidaka, H. H-Series Protein Kinase Inhibitors and Potential Clinical Applications. Pharmacol. Ther. 1999, 82, 123-131. [CrossRef]

61. Ohori, M.; Kinoshita, T.; Okubo, M.; Sato, K.; Yamazaki, A.; Arakawa, H.; Nishimura, S.; Inamura, N.; Nakajima, H.; Neya, M.; et al. Identification of a Selective ERK Inhibitor and Structural Determination of the Inhibitor-ERK2 Complex. Biochem. Biophys. Res. Commun. 2005, 336, 357-363. [CrossRef]

62. Wong, H.; Belvin, M.; Herter, S.; Hoeflich, K.P.; Murray, L.J.; Wong, L.; Choo, E.F. Pharmacodynamics of 2-\{4-[(1E)-1(Hydroxyimino)-2,3-Dihydro-1H-Inden-5-Yl]-3-(Pyridine-4-Yl)-1H-Pyrazol-1-Yl\}ethan-1-Ol (GDC-0879), a Potent and Selective B-Raf Kinase Inhibitor: Understanding Relationships between Systemic Concentrations, Phosphorylated Mitogen-Activated Protein Kinase Kinase 1 Inhibition, and Efficacy. J. Pharmacol. Exp. Ther. 2009, 329, 360-367. [CrossRef] 
63. Lansing, T.J.; McConnell, R.T.; Duckett, D.R.; Spehar, G.M.; Knick, V.B.; Hassler, D.F.; Noro, N.; Furuta, M.; Emmitte, K.A.; Gilmer, T.M.; et al. In Vitro Biological Activity of a Novel Small-Molecule Inhibitor of Polo-like Kinase 1. Mol. Cancer Ther. 2007, 6, 450-459. [CrossRef]

64. Leclerc, S.; Garnier, M.; Hoessel, R.; Marko, D.; Bibb, J.A.; Snyder, G.L.; Greengard, P.; Biernat, J.; Wu, Y.-Z.; Mandelkow, E.-M.; et al. Indirubins Inhibit Glycogen Synthase Kinase-3 $\beta$ and CDK5/P25, Two Protein Kinases Involved in Abnormal Tau Phosphorylation in Alzheimer's Disease a Property Common to Most Cyclin-Dependent Kinase Inhibitors? J. Biol. Chem. 2001, 276, 251-260. [CrossRef]

65. Waelchli, R.; Bollbuck, B.; Bruns, C.; Buhl, T.; Eder, J.; Feifel, R.; Hersperger, R.; Janser, P.; Revesz, L.; Zerwes, H.-G.; et al. Design and Preparation of 2-Benzamido-Pyrimidines as Inhibitors of IKK. Bioorg. Med. Chem. Lett. 2006, 16, 108-112. [CrossRef]

66. Heinrich, M.C.; Griffith, D.J.; Druker, B.J.; Wait, C.L.; Ott, K.A.; Zigler, A.J. Inhibition of C-Kit Receptor Tyrosine Kinase Activity by STI 571, a Selective Tyrosine Kinase Inhibitor. Blood 2000, 96, 925-932. [CrossRef] [PubMed]

67. Quintás-Cardama, A.; Vaddi, K.; Liu, P.; Manshouri, T.; Li, J.; Scherle, P.A.; Caulder, E.; Wen, X.; Li, Y.; Waeltz, P.; et al. Preclinical Characterization of the Selective JAK1/2 Inhibitor INCB018424: Therapeutic Implications for the Treatment of Myeloproliferative Neoplasms. Blood 2010, 115, 3109-3117. [CrossRef]

68. Emanuel, S.; Rugg, C.A.; Gruninger, R.H.; Lin, R.; Fuentes-Pesquera, A.; Connolly, P.J.; Wetter, S.K.; Hollister, B.; Kruger, W.W.; Napier, C.; et al. The In Vitro and In Vivo Effects of JNJ-7706621: A Dual Inhibitor of Cyclin-Dependent Kinases and Aurora Kinases. Cancer Res. 2005, 65, 9038-9046. [CrossRef]

69. Hickson, I.; Zhao, Y.; Richardson, C.J.; Green, S.J.; Martin, N.M.B.; Orr, A.I.; Reaper, P.M.; Jackson, S.P.; Curtin, N.J.; Smith, G.C.M. Identification and Characterization of a Novel and Specific Inhibitor of the Ataxia-Telangiectasia Mutated Kinase ATM. Cancer Res. 2004, 64, 9152-9159. [CrossRef] [PubMed]

70. Mader, M.; de Dios, A.; Shih, C.; Bonjouklian, R.; Li, T.; White, W.; de Uralde, B.L.; Sánchez-Martinez, C.; del Prado, M.; Jaramillo, C.; et al. Imidazolyl Benzimidazoles and Imidazo[4,5-b]Pyridines as Potent P38 $\alpha$ MAP Kinase Inhibitors with Excellent in Vivo Antiinflammatory Properties. Bioorg. Med. Chem. Lett. 2008, 18, 179-183. [CrossRef]

71. Manfredi, M.G.; Ecsedy, J.A.; Chakravarty, A.; Silverman, L.; Zhang, M.; Hoar, K.M.; Stroud, S.G.; Chen, W.; Shinde, V.; Huck, J.J.; et al. Characterization of Alisertib (MLN8237), an Investigational Small-Molecule Inhibitor of Aurora A Kinase Using Novel In Vivo Pharmacodynamic Assays. Clin. Cancer Res. 2011, 17, 7614-7624. [CrossRef]

72. Weisberg, E.; Catley, L.; Wright, R.D.; Moreno, D.; Banerji, L.; Ray, A.; Manley, P.W.; Mestan, J.; Fabbro, D.; Jiang, J.; et al. Beneficial Effects of Combining Nilotinib and Imatinib in Preclinical Models of BCR-ABL+ Leukemias. Blood 2007, 109, $2112-2120$. [CrossRef] [PubMed]

73. Jobson, A.G.; Cardellina, J.H.; Scudiero, D.; Kondapaka, S.; Zhang, H.; Kim, H.; Shoemaker, R.; Pommier, Y. Identification of a Bis-Guanylhydrazone [4,4'-Diacetyldiphenylurea-Bis(Guanylhydrazone); NSC 109555] as a Novel Chemotype for Inhibition of Chk2 Kinase. Mol. Pharmacol. 2007, 72, 876-884. [CrossRef]

74. Leahy, J.J.J.; Golding, B.T.; Griffin, R.J.; Hardcastle, I.R.; Richardson, C.; Rigoreau, L.; Smith, G.C.M. Identification of a Highly Potent and Selective DNA-Dependent Protein Kinase (DNA-PK) Inhibitor (NU7441) by Screening of Chromenone Libraries. Bioorg. Med. Chem. Lett. 2004, 14, 6083-6087. [CrossRef]

75. Barrett, S.D.; Bridges, A.J.; Dudley, D.T.; Saltiel, A.R.; Fergus, J.H.; Flamme, C.M.; Delaney, A.M.; Kaufman, M.; LePage, S.; Leopold, W.R.; et al. The Discovery of the Benzhydroxamate MEK Inhibitors CI-1040 and PD 0325901. Bioorg. Med. Chem. Lett. 2008, 18, 6501-6504. [CrossRef]

76. Palmer, B.D.; Thompson, A.M.; Booth, R.J.; Dobrusin, E.M.; Kraker, A.J.; Lee, H.H.; Lunney, E.A.; Mitchell, L.H.; Ortwine, D.F.; Smaill, J.B.; et al. 4-Phenylpyrrolo[3,4-c]Carbazole-1,3(2H,6H)-Dione Inhibitors of the Checkpoint Kinase Wee1. Structure-Activity Relationships for Chromophore Modification and Phenyl Ring Substitution. J. Med. Chem. 2006, 49, $4896-4911$. [CrossRef]

77. Pearce, L.R.; Alton, G.R.; Richter, D.T.; Kath, J.C.; Lingardo, L.; Chapman, J.; Hwang, C.; Alessi, D.R. Characterization of PF-4708671, a Novel and Highly Specific Inhibitor of P70 Ribosomal S6 Kinase (S6K1). Biochem. J. 2010, 431, 245-255. [CrossRef]

78. Slack-Davis, J.K.; Martin, K.H.; Tilghman, R.W.; Iwanicki, M.; Ung, E.J.; Autry, C.; Luzzio, M.J.; Cooper, B.; Kath, J.C.; Roberts, W.G.; et al. Cellular Characterization of a Novel Focal Adhesion Kinase Inhibitor. J. Biol. Chem. 2007, 282, 14845-14852. [CrossRef] [PubMed]

79. Fabbro, D.; Buchdunger, E.; Wood, J.; Mestan, J.; Hofmann, F.; Ferrari, S.; Mett, H.; O'Reilly, T.; Meyer, T. Inhibitors of Protein Kinases CGP 41251, a Protein Kinase Inhibitor with Potential as an Anticancer Agent. Pharmacol. Ther. 1999, 82, $293-301$. [CrossRef]

80. Bollag, G.; Hirth, P.; Tsai, J.; Zhang, J.; Ibrahim, P.N.; Cho, H.; Spevak, W.; Zhang, C.; Zhang, Y.; Habets, G.; et al. Clinical Efficacy of a RAF Inhibitor Needs Broad Target Blockade in BRAF-Mutant Melanoma. Nature 2010, 467, 596-599. [CrossRef]

81. Tsai, J.; Lee, J.T.; Wang, W.; Zhang, J.; Cho, H.; Mamo, S.; Bremer, R.; Gillette, S.; Kong, J.; Haass, N.K.; et al. Discovery of a Selective Inhibitor of Oncogenic B-Raf Kinase with Potent Antimelanoma Activity. Proc. Natl. Acad. Sci. USA 2008, 105, 3041-3046. [CrossRef]

82. Wilkinson, S.E.; Parker, P.J.; Nixon, J.S. Isoenzyme Specificity of Bisindolylmaleimides, Selective Inhibitors of Protein Kinase C. Biochem. J. 1993, 294, 335-337. [CrossRef] [PubMed] 
83. Meijer, L.; Borgne, A.; Mulner, O.; Chong, J.P.J.; Blow, J.J.; Inagaki, N.; Inagaki, M.; Delcros, J.; Moulinoux, J. Biochemical and Cellular Effects of Roscovitine, a Potent and Selective Inhibitor of the Cyclin-Dependent Kinases Cdc2, Cdk2 and Cdk5. Eur. J. Biochem. 1997, 243, 527-536. [CrossRef]

84. Coghlan, M.P.; Culbert, A.A.; Cross, D.A.; Corcoran, S.L.; Yates, J.W.; Pearce, N.J.; Rausch, O.L.; Murphy, G.J.; Carter, P.S.; Cox, L.R.; et al. Selective Small Molecule Inhibitors of Glycogen Synthase Kinase-3 Modulate Glycogen Metabolism and Gene Transcription. Chem. Biol. 2000, 7, 793-803. [CrossRef]

85. Jackson, J.R.; Gilmartin, A.; Imburgia, C.; Winkler, J.D.; Marshall, L.A.; Roshak, A. An Indolocarbazole Inhibitor of Human Checkpoint Kinase (Chk1) Abrogates Cell Cycle Arrest Caused by DNA Damage. Cancer Res. 2000, 60, 566-572.

86. Conroy, A.; Stockett, D.E.; Walker, D.; Arkin, M.R.; Hoch, U.; Fox, J.A.; Hawtin, R.E. SNS-032 Is a Potent and Selective CDK 2, 7 and 9 Inhibitor That Drives Target Modulation in Patient Samples. Cancer Chemother. Pharmacol. 2009, 64, 723-732. [CrossRef]

87. Oslob, J.D.; Romanowski, M.J.; Allen, D.A.; Baskaran, S.; Bui, M.; Elling, R.A.; Flanagan, W.M.; Fung, A.D.; Hanan, E.J.; Harris, S.; et al. Discovery of a Potent and Selective Aurora Kinase Inhibitor. Bioorg. Med. Chem. Lett. 2008, 18, 4880-4884. [CrossRef]

88. Bennett, B.L.; Sasaki, D.T.; Murray, B.W.; O’Leary, E.C.; Sakata, S.T.; Xu, W.; Leisten, J.C.; Motiwala, A.; Pierce, S.; Satoh, Y.; et al. SP600125, an Anthrapyrazolone Inhibitor of Jun N-Terminal Kinase. Proc. Natl. Acad. Sci. USA 2001, 98, 13681-13686. [CrossRef]

89. Pagano, M.A.; Poletto, G.; Maira, G.D.; Cozza, G.; Ruzzene, M.; Sarno, S.; Bain, J.; Elliott, M.; Moro, S.; Zagotto, G.; et al. Tetrabromocinnamic Acid (TBCA) and Related Compounds Represent a New Class of Specific Protein Kinase CK2 Inhibitors. ChemBioChem 2007, 8, 129-139. [CrossRef] [PubMed]

90. Teng, M.; Zhu, J.; Johnson, M.D.; Chen, P.; Kornmann, J.; Chen, E.; Blasina, A.; Register, J.; Anderes, K.; Rogers, C.; et al. Structure-Based Design of (5-Arylamino-2 H -Pyrazol-3-Yl)-Biphenyl-2',4'-Diols as Novel and Potent Human CHK1 Inhibitors. J. Med. Chem. 2007, 50, 5253-5256. [CrossRef]

91. Cheney, I.W.; Yan, S.; Appleby, T.; Walker, H.; Vo, T.; Yao, N.; Hamatake, R.; Hong, Z.; Wu, J.Z. Identification and StructureActivity Relationships of Substituted Pyridones as Inhibitors of Pim-1 Kinase. Bioorg. Med. Chem. Lett. 2007, 17, 1679-1683. [CrossRef] [PubMed]

92. Beharry, Z.; Zemskova, M.; Mahajan, S.; Zhang, F.; Ma, J.; Xia, Z.; Lilly, M.; Smith, C.D.; Kraft, A.S. Novel BenzylideneThiazolidine-2,4-Diones Inhibit Pim Protein Kinase Activity and Induce Cell Cycle Arrest in Leukemia and Prostate Cancer Cells. Mol. Cancer Ther. 2009, 8, 1473-1483. [CrossRef]

93. Harrington, E.A.; Bebbington, D.; Moore, J.; Rasmussen, R.K.; Ajose-Adeogun, A.O.; Nakayama, T.; Graham, J.A.; Demur, C.; Hercend, T.; Diu-Hercend, A.; et al. VX-680, a Potent and Selective Small-Molecule Inhibitor of the Aurora Kinases, Suppresses Tumor Growth in Vivo. Nat. Med. 2004, 10, 262-267. [CrossRef]

94. Cheetham, G.M.T.; Charlton, P.A.; Golec, J.M.C.; Pollard, J.R. Structural Basis for Potent Inhibition of the Aurora Kinases and a T315I Multi-Drug Resistant Mutant Form of Abl Kinase by VX-680. Cancer Lett. 2007, 251, 323-329. [CrossRef] [PubMed]

95. Podolin, P.L.; Callahan, J.F.; Bolognese, B.J.; Li, Y.H.; Carlson, K.; Davis, T.G.; Mellor, G.W.; Evans, C.; Roshak, A.K. Attenuation of Murine Collagen-Induced Arthritis by a Novel, Potent, Selective Small Molecule Inhibitor of IkB Kinase 2, TPCA-1 (2[(Aminocarbonyl)Amino]-5-(4-Fluorophenyl)-3-Thiophenecarboxamide), Occurs via Reduction of Proinflammatory Cytokines and Antigen-Induced T Cell Proliferation. J. Pharmacol. Exp. Ther. 2005, 312, 373-381. [CrossRef]

96. Duncia, J.V.; Santella, J.B.; Higley, C.A.; Pitts, W.J.; Wityak, J.; Frietze, W.E.; Rankin, F.W.; Sun, J.-H.; Earl, R.A.; Tabaka, A.C.; et al. MEK Inhibitors: The Chemistry and Biological Activity of U0126, Its Analogs, and Cyclization Products. Bioorg. Med. Chem. Lett. 1998, 8, 2839-2844. [CrossRef]

97. Kuliopulos, A.; Mohanlal, R.; Covic, L. Effect of Selective Inhibition of the P38 MAP Kinase Pathway on Platelet Aggregation. Thromb. Haemost. 2004, 92, 1387-1393. [CrossRef]

98. Uehata, M.; Ishizaki, T.; Satoh, H.; Ono, T.; Kawahara, T.; Morishita, T.; Tamakawa, H.; Yamagami, K.; Inui, J.; Maekawa, M.; et al. Calcium Sensitization of Smooth Muscle Mediated by a Rho-Associated Protein Kinase in Hypertension. Nature 1997, 389, 990-994. [CrossRef]

99. Ishizaki, T.; Uehata, M.; Tamechika, I.; Keel, J.; Nonomura, K.; Maekawa, M.; Narumiya, S. Pharmacological Properties of Y-27632, a Specific Inhibitor of Rho-Associated Kinases. Mol. Pharmacol. 2000, 57, 976-983.

100. Ditchfield, C.; Johnson, V.L.; Tighe, A.; Ellston, R.; Haworth, C.; Johnson, T.; Mortlock, A.; Keen, N.; Taylor, S.S. Aurora B Couples Chromosome Alignment with Anaphase by Targeting BubR1, Mad2, and Cenp-E to Kinetochores. J. Cell Biol. 2003, 161, 267-280. [CrossRef]

101. Duong, H.-Q.; You, K.; Oh, S.; Kwak, S.-J.; Seong, Y.-S. Silencing of NRF2 Reduces the Expression of ALDH1A1 and ALDH3A1 and Sensitizes to 5-FU in Pancreatic Cancer Cells. Antioxidants 2017, 6, 52. [CrossRef]

102. Jin, Q.; Esteva, F.J. Cross-Talk Between the ErbB/HER Family and the Type I Insulin-Like Growth Factor Receptor Signaling Pathway in Breast Cancer. J. Mammary Gland Biol. 2008, 13, 485-498. [CrossRef]

103. Karamouzis, M.V.; Konstantinopoulos, P.A.; Papavassiliou, A.G. Targeting MET as a Strategy to Overcome Crosstalk-Related Resistance to EGFR Inhibitors. Lancet Oncol. 2009, 10, 709-717. [CrossRef]

104. Liu, P.; Cheng, H.; Roberts, T.M.; Zhao, J.J. Targeting the Phosphoinositide 3-Kinase Pathway in Cancer. Nat. Rev. Drug Discov. 2009, 8, 627-644. [CrossRef]

105. Nahta, R.; Yu, D.; Hung, M.-C.; Hortobagyi, G.N.; Esteva, F.J. Mechanisms of Disease: Understanding Resistance to HER2-Targeted Therapy in Human Breast Cancer. Nat. Clin. Pract. Oncol. 2006, 3, 269-280. [CrossRef] 
106. Yamaguchi, H.; Chang, S.-S.; Hsu, J.L.; Hung, M.-C. Signaling Cross-Talk in the Resistance to HER Family Receptor Targeted Therapy. Oncogene 2014, 33, 1073-1081. [CrossRef]

107. Baselga, J. Targeting Tyrosine Kinases in Cancer: The Second Wave. Science 2006, 312, 1175-1178. [CrossRef]

108. Heil, J.; Reifferscheid, G.; Waldmann, P.; Leyhausen, G.; Geurtsen, W. Genotoxicity of Dental Materials. Mutat. Res. Genet. Toxicol. 1996, 368, 181-194. [CrossRef]

109. Meyuhas, O. Ribosomal Protein S6 Phosphorylation Four Decades of Research. Int. Rev. Cell Mol. Biol. 2015, 320, 41-73. [CrossRef]

110. Chandarlapaty, S.; Sawai, A.; Scaltriti, M.; Rodrik-Outmezguine, V.; Grbovic-Huezo, O.; Serra, V.; Majumder, P.K.; Baselga, J.; Rosen, N. AKT Inhibition Relieves Feedback Suppression of Receptor Tyrosine Kinase Expression and Activity. Cancer Cell 2011, 19, 58-71. [CrossRef]

111. Serra, V.; Scaltriti, M.; Prudkin, L.; Eichhorn, P.J.A.; Ibrahim, Y.H.; Chandarlapaty, S.; Markman, B.; Rodriguez, O.; Guzman, M.; Rodriguez, S.; et al. PI3K Inhibition Results in Enhanced HER Signaling and Acquired ERK Dependency in HER2-Overexpressing Breast Cancer. Oncogene 2011, 30, 2547-2557. [CrossRef]

112. Chakrabarty, A.; Sánchez, V.; Kuba, M.G.; Rinehart, C.; Arteaga, C.L. Feedback Upregulation of HER3 (ErbB3) Expression and Activity Attenuates Antitumor Effect of PI3K Inhibitors. Proc. Natl. Acad. Sci. USA 2012, 109, 2718-2723. [CrossRef] [PubMed]

113. Garrett, J.T.; Olivares, M.G.; Rinehart, C.; Granja-Ingram, N.D.; Sánchez, V.; Chakrabarty, A.; Dave, B.; Cook, R.S.; Pao, W.; McKinely, E.; et al. Transcriptional and Posttranslational Up-Regulation of HER3 (ErbB3) Compensates for Inhibition of the HER2 Tyrosine Kinase. Proc. Natl. Acad. Sci. USA 2011, 108, 5021-5026. [CrossRef]

114. Kajstura, M.; Halicka, H.D.; Pryjma, J.; Darzynkiewicz, Z. Discontinuous Fragmentation of Nuclear DNA during Apoptosis Revealed by Discrete "Sub-G1" Peaks on DNA Content Histograms. Cytom. Part A 2007, 71A, 125-131. [CrossRef] [PubMed]

115. Umansky, S.R.; Korol', B.A.; Nelipovich, P.A. In Vivo DNA Degradation in Thymocytes of $\gamma$-Irradiated or Hydrocortisone-Treated Rats. BBA Nucleic Acids Protein Synth. 1981, 655, 9-17. [CrossRef]

116. Telford, W.G.; King, L.E.; Fraker, P.J. Evaluation of Glucocorticoid-induced DNA Fragmentation in Mouse Thymocytes by Flow Cytometry. Cell Prolif. 1991, 24, 447-459. [CrossRef]

117. Telford, W.G.; King, L.E.; Fraker, P.J. Comparative Evaluation of Several DNA Binding Dyes in the Detection of Apoptosisassociated Chromatin Degradation by Flow Cytometry. Cytometry 1992, 13, 137-143. [CrossRef]

118. Gong, J.P.; Traganos, F.; Darzynkiewicz, Z. A Selective Procedure for DNA Extraction from Apoptotic Cells Applicable for Gel Electrophoresis and Flow Cytometry. Anal. Biochem. 1994, 218, 314-319. [CrossRef]

119. Darzynkiewicz, Z.; Juan, G.; Li, X.; Gorczyca, W.; Murakami, T.; Traganos, F. Cytometry in Cell Necrobiology: Analysis of Apoptosis and Accidental Cell Death (Necrosis). Cytometry 1997, 27, 1-20. [CrossRef]

120. Aird, K.M.; Ghanayem, R.B.; Peplinski, S.; Lyerly, H.K.; Devi, G.R. X-Linked Inhibitor of Apoptosis Protein Inhibits Apoptosis in Inflammatory Breast Cancer Cells with Acquired Resistance to an ErbB1/2 Tyrosine Kinase Inhibitor. Mol. Cancer Ther. 2010, 9, 1432-1442. [CrossRef]

121. Kim, S.; You, D.; Jeong, Y.; Yu, J.; Kim, S.W.; Nam, S.J.; Lee, J.E. Berberine Down-Regulates IL-8 Expression through Inhibition of the EGFR/MEK/ERK Pathway in Triple-Negative Breast Cancer Cells. Phytomedicine 2018, 50, 43-49. [CrossRef]

122. Song, X.; Liu, Z.; Yu, Z. EGFR Promotes the Development of Triple Negative Breast Cancer through JAK/STAT3 Signaling. Cancer Manag. Res. 2020, 12, 703-717. [CrossRef]

123. Sohn, J.; Liu, S.; Parinyanitikul, N.; Lee, J.; Hortobagyi, G.N.; Mills, G.B.; Ueno, N.T.; Gonzalez-Angulo, A.M. CMET Activation and EGFR-Directed Therapy Resistance in Triple-Negative Breast Cancer. J. Cancer 2014, 5, 745-753. [CrossRef]

124. Simiczyjew, A.; Dratkiewicz, E.; Troys, M.V.; Ampe, C.; Styczeń, I.; Nowak, D. Combination of EGFR Inhibitor Lapatinib and MET Inhibitor Foretinib Inhibits Migration of Triple Negative Breast Cancer Cell Lines. Cancers 2018, 10, 335. [CrossRef] [PubMed]

125. Li, W.; Hou, J.-Z.; Niu, J.; Xi, Z.-Q.; Ma, C.; Sun, H.; Wang, C.-J.; Fang, D.; Li, Q.; Xie, S.-Q. Akt1 Inhibition Promotes Breast Cancer Metastasis through EGFR-Mediated $\beta$-Catenin Nuclear Accumulation. Cell Commun. Signal. 2018, 16, 82. [CrossRef]

126. Fleisher, B.; Mody, H.; Werkman, C.; Ait-Oudhia, S. Chloroquine Sensitizes MDA-MB-231 Cells to Osimertinib through Autophagy-Apoptosis Crosstalk Pathway. Breast Cancer Targets Ther. 2019, 11, 231-241. [CrossRef]

127. Guerrab, A.E.; Bamdad, M.; Bignon, Y.-J.; Penault-Llorca, F.; Aubel, C. Co-Targeting EGFR and MTOR with Gefitinib and Everolimus in Triple-Negative Breast Cancer Cells. Sci. Rep. 2020, 10, 6367. [CrossRef]

128. Cossu-Rocca, P.; Orrù, S.; Muroni, M.R.; Sanges, F.; Sotgiu, G.; Ena, S.; Pira, G.; Murgia, L.; Manca, A.; Uras, M.G.; et al. Analysis of PIK3CA Mutations and Activation Pathways in Triple Negative Breast Cancer. PLoS ONE 2015, 10, e0141763. [CrossRef]

129. Pao, W.; Wang, T.Y.; Riely, G.J.; Miller, V.A.; Pan, Q.; Ladanyi, M.; Zakowski, M.F.; Heelan, R.T.; Kris, M.G.; Varmus, H.E. KRAS Mutations and Primary Resistance of Lung Adenocarcinomas to Gefitinib or Erlotinib. PLoS Med. 2005, 2, e17. [CrossRef]

130. Jiang, W.; Wang, X.; Zhang, C.; Xue, L.; Yang, L. Expression and Clinical Significance of MAPK and EGFR in Triple-Negative Breast Cancer. Oncol. Lett. 2020, 19, 1842-1848. [CrossRef]

131. Bartholomeusz, C.; Gonzalez-Angulo, A.M.; Liu, P.; Hayashi, N.; Lluch, A.; Ferrer-Lozano, J.; Hortobágyi, G.N. High ERK Protein Expression Levels Correlate with Shorter Survival in Triple-Negative Breast Cancer Patients. Oncologist 2012, 17, 766-774. [CrossRef]

132. Gholami, S.; Chen, C.-H.; Gao, S.; Lou, E.; Fujisawa, S.; Carson, J.; Nnoli, J.E.; Chou, T.-C.; Bromberg, J.; Fong, Y. Role of MAPK in Oncolytic Herpes Viral Therapy in Triple-Negative Breast Cancer. Cancer Gene Ther. 2014, 21, 283-289. [CrossRef] [PubMed] 
133. Hoeflich, K.P.; O’Brien, C.; Boyd, Z.; Cavet, G.; Guerrero, S.; Jung, K.; Januario, T.; Savage, H.; Punnoose, E.; Truong, T.; et al. In Vivo Antitumor Activity of MEK and Phosphatidylinositol 3-Kinase Inhibitors in Basal-Like Breast Cancer Models. Clin. Cancer Res. 2009, 15, 4649-4664. [CrossRef] [PubMed]

134. Koboldt, D.C.; Fulton, R.S.; McLellan, M.D.; Schmidt, H.; Kalicki-Veizer, J.; McMichael, J.F.; Fulton, L.L.; Dooling, D.J.; Ding, L.; Mardis, E.R.; et al. Comprehensive Molecular Portraits of Human Breast Tumours. Nature 2012, 490, 61-70. [CrossRef]

135. Zhao, M.; Howard, E.W.; Parris, A.B.; Guo, Z.; Zhao, Q.; Yang, X. Alcohol Promotes Migration and Invasion of Triple-negative Breast Cancer Cells through Activation of P38 MAPK and JNK. Mol. Carcinog. 2017, 56, 849-862. [CrossRef]

136. Uehara, N.; Kanematsu, S.; Miki, H.; Yoshizawa, K.; Tsubura, A. Requirement of P38 MAPK for a Cell-Death Pathway Triggered by Vorinostat in MDA-MB-231 Human Breast Cancer Cells. Cancer Lett. 2012, 315, 112-121. [CrossRef]

137. Peng, B.; He, R.; Xu, Q.; Yang, Y.; Hu, Q.; Hou, H.; Liu, X.; Li, J. Ginsenoside 20(S)-Protopanaxadiol Inhibits Triple-Negative Breast Cancer Metastasis in Vivo by Targeting EGFR-Mediated MAPK Pathway. Pharmacol. Res. 2019, 142, 1-13. [CrossRef] [PubMed]

138. Duncan, J.S.; Whittle, M.C.; Nakamura, K.; Abell, A.N.; Midland, A.A.; Zawistowski, J.S.; Johnson, N.L.; Granger, D.A.; Jordan, N.V.; Darr, D.B.; et al. Dynamic Reprogramming of the Kinome in Response to Targeted MEK Inhibition in Triple-Negative Breast Cancer. Cell 2012, 149, 307-321. [CrossRef]

139. Swearingen, A.E.D.V.; Sambade, M.J.; Siegel, M.B.; Sud, S.; McNeill, R.S.; Bevill, S.M.; Chen, X.; Bash, R.E.; Mounsey, L.; Golitz, B.T.; et al. Combined Kinase Inhibitors of MEK1/2 and Either PI3K or PDGFR Are Efficacious in Intracranial Triple-Negative Breast Cancer. Neuro Oncol. 2017, 19, 1481-1493. [CrossRef] [PubMed]

140. Park, B.J.; Whichard, Z.L.; Corey, S.J. Dasatinib Synergizes with Both Cytotoxic and Signal Transduction Inhibitors in Heterogeneous Breast Cancer Cell Lines-Lessons for Design of Combination Targeted Therapy. Cancer Lett. 2012, 320, 104-110. [CrossRef] [PubMed]

141. Ramaswamy, B.; Mrozek, E.; Lustberg, M.; Wesolowski, R.; Layman, R.; Abdel-Rasoul, M.; Timmers, C.; Patrick, R.; Sexton, J.; Macrae, E.; et al. Abstract LB-216: NCI 9455: Phase II Study of Trametinib Followed by Trametinib plus AKT Inhibitor, GSK2141795 in Patients with Advanced Triple Negative Breast Cancer. In Proceedings of the AACR 107th Annual Meeting, New Orleans, LA, USA, 16-20 April 2016. [CrossRef] 